\title{
The Mutual Benefits from Sino-Africa Trade: Evidence on Emission Transfer along the Global Supply Chain
}

\author{
Xi Ji a,b,*, Yifang Liu ${ }^{\text {a }}$, Mengyao Han ${ }^{\text {c,d,e }}$, Jing Meng ${ }^{\mathrm{f}}$ \\ a School of Economics, Peking University, Beijing 100871, P.R. China \\ ${ }^{\mathrm{b}}$ Institute of Energy Economy and Sustainability Development Research (IEESDR), Peking \\ University, Beijing 100871, China \\ ${ }^{\mathrm{c}}$ Institute of Geographic Sciences and Natural Resources Research, Chinese Academy of Sciences, \\ Beijing 100101, P.R. China \\ d Key Laboratory of Regional Sustainable Development Modeling, Chinese Academy of Sciences, \\ Beijing 100101, P.R. China \\ ${ }^{\text {e }}$ College of Resources and Environment, University of Chinese Academy of Sciences, Beijing \\ 100049, P.R. China \\ ${ }^{\mathrm{f}}$ The Bartlett School of Construction and Project Management, University College London, \\ London WC1E 7HB, UK
}

\section{Highlights}

- Historical trend of embodied carbon transfer between China-Africa Forum participants is explored.

- Carbon-emission in China related to Africa's consumption well surpassed that vice versa.

- Sino-Africa trade has relieved the carbon-emission pressure on Africa's economic development.

- Sectoral contribution of embodied carbon-emission reflects the complementarity between China and Africa.

- Embodied carbon-emission intensities of both China and Africa have declined.

\footnotetext{
*Corresponding author at: School of Economics, Peking University, Beijing, 100871, PR China. Tel: +86010 62755283. E-mail address: jixi@pku.edu.cn (Xi Ji).
} 


\begin{abstract}
The carbon-emission transfer between two representative developing economies China and Africa - behind the international trade has aroused quite a few controversies, which have not been fully estimated and understood yet. In this paper, the Multiregional Input-Output (MRIO) method is applied to the participants of Forum on China-Africa Cooperation (FOCAC) from the global perspective to reveal the roles both China and Africa have played in the global supply chain as either the original emitter or the final consumer, and to depict the evolution pattern of carbon transfer via Sino-Africa trade from the year 2000 to 2015 . The findings are as follows: 1) China has played the role of net exporter of embodied carbon-emission in Sino-Africa trade, for the amount of emitted carbon China had born yet resulted by consumption in Africa well surpassed that vice versa. 2) Compared to the carbon-emission flows embodied in EU-Africa and US-Africa trades, China has shouldered more carbon-emission derived from Africa's consumption. 3 ) The sectoral contribution and intensities of embodied carbon-emission correspond to the trading pattern between China and Africa, which stems from the two parties' comparative advantages and economic complementarity. 4) The intensities of embodied carbon-emission on both sides are declining towards a rosy prospect, which indicates an improving carbon-emission efficiency of both economies. From a global perspective, both China and Africa play a positive part in carbon-emission reduction. The results in this study can facilitate low-carbon, high-efficiency trading link between the two economies.
\end{abstract}

Keywords: China-Africa Cooperation Forum; Sino-Africa trade; Multiregional Input-Output analysis; Embodied carbon-emission; Mutual benefits 


\section{Introduction}

As the two major poles in the Third World, China and Africa have forged a time-honored political and trading link. In 2000, China and 53 African countries, alongside the African Union Commission, co-founded the Forum on China-Africa Cooperation (FOCAC) and arrived at a consensus about industrial development, infrastructure connectivity, trade facilitation, and green development. Since the foundation, mutual trade, investment, and development have all soared exponentially, as China-Africa cooperation advances to a higher and more profound level, Sino-Africa trade has cemented its role in the big picture of international trading and has become a paragon of South-South Cooperation. In 2009, China beat the EU and became Africa's biggest trading partner. During the first half of 2019, total exports and imports between China and Africa has reached 99.84 billion dollars - a 17.3\% year-on-year growth, and the import growth rate ranks first across the globe.

With the growing tendency of economic globalization, major economic bodies have all integrated themselves into the global value chain, and it has become a ubiquitous phenomenon for countries sitting atop the chain to transfer their downstream industries to the less developed countries. Economic globalization and international trade provide a brand-new mechanism for global reallocation of production factors energy, capital, technology, and others, which in part reshapes the production activities and greenhouse gas emissions of everyone (Ji and Long, 2016; Geng et al., 2017; Zhang et al., 2018; Meng et al., 2018a; Matsumo to et al., 2018; Nabernegg et al., 2019; Long and Ji, 2019). China happens to be the second-largest oil-consumption country as well as the most significant aluminum and iron ore consumer and the greatest tropical timber importer (IEA, 2018; FAO, 2018). The natural resource has always been a critical sector both in China-Africa investment and Africa-China exportation, while industrial end products and semi-manufactured products take up a considerable proportion of Sino-African trade. The African economy is built on a long-stand, resource-unitary structure mainly of crops and ores, with an oversized 
agriculture sector, a comparatively weak economic base, and a low level of manufacture (Ji et al., 2018). Despite its primitive manufacture level, Africa has high potentials, its vast land, plentiful natural resources, and cheap labor, all adding its odds of manufacturing development. Africa might become the next world manufacturing factory. On the other hand, energy acts as the impetus of economic growth, and the flip side of economic development is immense energy consumption and carbon-emission (Richmond and Kaufmann, 2006; Shahbaz et al., 2013; Al-mulali and Sheau-Ting, 2014; Fernández-Amador et al., 2017). For Africa, economic development should be the cardinal goal. Hence, an increasing trend in Africa's carbon-emission seems inevitable. Africa will likely become a new highland of the global carbon-emission growth map, as growing importance will be attached to relevant climate change and other environmental problems.

Since the strengthened commodity and energy trading link between China and Africa could impact global resource, industrial allocation, and carbon-emission, existing literature questions Sino-Africa trade from the perspective of trading pattern and the industrial transfer. Some scholars state that in terms of the trading patterns of capital and resources between the two parties, China's purchase of Africa's energy and raw material contributes little to Africa's economic development (Peh and Eyal, 2010), with a limited scope and a giant allocation gap (Large, 2008; Obuah, 2012). Even worse, the trade might increase the instability of Africa's economy by influencing the global price of raw materials (Kummer-Noormamode, 2014). According to certain studies, China-Africa manufacture export might impair the local manufacture sector (Peh and Eyal, 2010), mutilating Africa's manufacturing potential (Foster, 2009; Adisu et al., 2010; Kolstad and Wiig, 2011). The manufacture and raw material flow between the two economies might also hamper Africa's industrialization and economic development (Kaplinsky and Morris, 2008; Giovannettia and Sanfilippo, 2009). As for the industrial transfer, some scholars state that the carbon-emission conundrum has resurrected in Africa due to the transfer of China's resource or carbon-intensive industries (Peh and Eyal, 2010). 
Existing literature has responded to the above questions. In terms of Africa's economic development, some scholars propose that Sino-Africa trade helps exploit Africa's natural resources as well as economic potential (Eisenman, 2012), improve its trading conditions (Kummer-Noormamode, 2014), and boost national wealth and income of the major importers and exporters (Broadman, 2006; Baliamoune-Lutz, 2011; Montinari and Prodi, 2011; Mulling and Mahabir, 2018). As for international relations, certain studies have pointed out that China's investment and trade in Africa posed an opportunity to both parties, rather than a one-sided neo-colonialism and natural wealth plunder. Compared with that between Africa and the western parties, the relationship between China and Africa is more balanced (Davies, 2008; Berthelemy, 2011; Jefferis, 2012). In general, the debate focuses on the perspective of economic values. Current doubts and questions mainly focus on the Sino-Africa trading pattern's threat to Africa's industrialization and economic stability, and the potential damage China's industrial transfer might do to Africa's resources and environment, and others. The responses to such questions mainly focus on the empirical analysis of the relevant economic development index. However, few studies manage to address the problem quantitively. By far, only Huang et al. (2017) have analyzed the resource flow via trade and assessed Sino-Africa trade's impact on the environment through emergy analysis.

Carbon-emission transfer not only takes place in industrial transfer, but it is also embodied in international trades. Under the production-perspective carbon-emission system, the exporters bear the responsibility of emitting carbon during the process for producing the commodities, while the importers fail to shoulder its responsibility of carbon-emission embodied in their consumption (Han et al., 2018). In other words, the importers shift its carbon-emission responsibilities to the exporters via transnational trades. Globalization and international trade have separated the process of production and consumption (Hertwich and Peters, 2009; Chen et al., 2016; Meng et al., 2018b; Ji et al., 2020), and hence the shift of carbon-emission responsibility (Peters et al., 2011; Hu et al., 2016; Zhong et al., 2018; Cadarso et al., 2018). 
Therefore, when studying the impact of trade on Africa's environment, we must not only stress on the carbon-emission transfer resulted by industrial transfer but also that embodied in trading commodities and services (Wiedmann et al., 2007; Wiebe et al, 2012; López et al., 2013). A scientific, systematic evaluation of the gross impact should take both the intermediate production and the final consumption. Though carbon-emission transfer cross border via trade has stirred up certain concern for the potential climate and environmental problems China's exportation might lead to (Paltsev, 2001; Peters and Hertwich, 2008; Su and Ang, 2011; Dietzenbacher et al., 2012; Su and Thomson, 2016; Long et al., 2018; Li et al., 2018), few studies have addressed the impact of Sino-Africa trade on Africa's carbon-emission. Existing literature mainly focuses on the carbon-emission transfer between developed countries and the developing ones (Liu et al., 2010; Choi et al., 2015), while little literature focuses on developing countries. The study of Meng et al. (2018a) is the most typical one among the minimal studies on embodied carbon-emission between developing countries, in which the authors explore and analyze the rising south-south trade's effect on global carbon-emission.

In this paper, we apply the Multiregional Input-Output method (MRIO) to calculate the aggregated embodied carbon transfer via Sino-Africa trade, depict its structure and trend, and attribute rationally the responsibility for carbon-emission derived from consumption by views of embodied analys is. We focus on the participants of FOCAC and analyze the total amount, sectoral contribution, and intensity of embodied carbon incurred by final demand via Sino-Africa trade and its structural trend since the foundation of the forum (the year 2000 to 2015). We hope to determine the carbon-emission flows from the consumer's perspective, and to make a more detailed and in-depth analysis of African countries that have a significant carbon-flow relationship with China.

Compared with existing literature, this study provides insight into two aspects. Firstly, in response to the questioning of China's environmental impact on Africa via 
Sino-Africa trade, this study beats a new path - taking carbon-emission as a prior index and applying the MRIO to explore the embodied carbon-emission behind Sino-Africa trade. This method would not only reveal the true nature of trading-incurred environmental issues, but can also unveil trading's systematic effect on regional carbon-emission, hence a new angle on the subject. Secondly, this study expands the coverage of the literature on embodied carbon-emission. On one hand, existing literature mainly concentrates on a global or regional perspective or focuses on the carbon transfer from developed to developing economies, while little has explored the link between China and Africa - two typical developing economies. On the other hand, this study covers fifteen years instead of one specific year, which can better reflect the pattern and tendency of carbon-emission behind trade. With two typical developing economies as subjects and embodied carbon-emission as the target, this research is a supplement and a beneficial expansion of existing literature, especially an insight for China and Africa in the field of trade and environmental issues. Through the quantitative analysis, we aim to explore the nature of Sion-Africa trade and carbon-emission flows and by final, a more scientific definition of Sion-Africa trade relations.

\section{Method and data source}

\subsection{Method}

Input-Output analysis can quantitively depict the commodities and service flows through the whole economic system, reveal the input and output of relevant economic sectors, and has been widely applied in macroeconomic studies (Leontief and Ford, 1970). The Multiregional Input-Output method stems from the original Input-Output analysis and has been widely used to explore the relationship between resource s and economic analysis (Han and Chen, 2018; Wu and Chen, 2018; Wu et al., 2019). Introducing carbon-emission into the chart, the MRIO can calculates the carbon-emission incurred in intermediate trade and final demand, thus depicts the whole picture of cross-region carbon-emission transfer via social and economic 
activities (Wiedmann, 2009; Tukker and Dietzenbacher, 2013; Steen-Olsen, 2014; Mi et al., 2017; Liu et al., 2018). Researches on global embodied carbon-emission have drawn a great deal of attention and flourished rapidly (Pan et al., 2008; Chen et al., 2010; Su and Ang, 2012; Arce et al., 2016; Zhu et al., 2018). Under the MRIO framework, embodied carbon flows across borders via commodities and service trades. Applying such model, we can attribute the emitted carbon embodied in final consumption to their real consumer by calculating the input and output relations between different regions and different sectors, reveal the inter-relationships among different economic bodies and sectors, and finally evaluate the impact of embodied carbon transfer on the social-economic system.

Based on the Eora Input-output table (Lenzen et al., 2012, 2013) and regional carbon-emission charts, we calculate local emissions related to the final consumption elsewhere, the emitted carbon embodied in the final demand of each country, and thus get the embodied carbon transfer between major economic bodies via international trades. Table 1 is the Multiregional Input-Output table, which can reveal the input-output links among a total of $a$ regions and $b$ sectors.

Based on the multi-regional input-output method, the total output of sector $\mathrm{i}$ in region $\mathrm{m}$ can be expressed as:

$$
x_{i}^{m}=\sum_{n=1}^{a} \sum_{j=1}^{b} z_{i j}^{m n}+\sum_{n=1}^{a} f_{i}^{m n},
$$

where $z_{i j}^{m n}$ represents the intermediate output from sector $j$ in region $n$ to sector $i$ in region $m, f_{i}^{m n}$ represents the final demand of sector $i$ from region $m$ to region $n$. The above equation can be expressed in a matrix form of:

$$
X=A X+F,
$$

Then we can get:

$$
X=(I-A)^{-1} F
$$


The embodied carbon-emission intensity of the final products is:

$$
E=D X^{-1}(I-A)^{-1}
$$

The intensity (unit output value of embodied carbon-emission) of matrix $E$ is used to analyze the embodied carbon flow of intermediate products and consumer goods in import and export trade.

The carbon-emission embodied in the final demand is expressed as:

$$
Q_{f}=D X^{-1}(I-A)^{-1} F=D X^{-1} B F
$$

where $D$ is a vector for direct carbon-emission of each sector; $X$ is sectoral total outputs; $A$ is input coefficient of each sector $\left(A=Z \bar{X}^{-1}\right), Z$ is intermediate input-output matrix, $X$ is diagonalized total output matrix; $B=(I-A)^{-1}$ represents Leontief inverse matrix, which captures both direct and indirect inputs to satisfy one unit of final demand in monetary value; $F$ is the final demand.

Under this framework, the above carbon-emission transfer from region $\mathrm{r}$ to region $\mathrm{s}$ is:

$$
q^{m n}=\sum_{k} d^{m} \hat{x}^{m-1} B^{m k^{-1}} f^{k n} .
$$

Through the MRIO framework, the carbon-emission transfer can be divided into two parts: the carbon-emission embodied in final products produced by region $m$ and the carbon-emission embodied in intermediate products produced by region $m$ and then exported to other regions, ultimately consumed by region $n$. The equation can be expressed as:

$$
q^{m n}=d^{m} \hat{x}^{m-1} B^{m m} f^{m n}+\sum_{k \neq m} d^{m} \hat{x}^{m-1} B^{m k} f^{k n} .
$$

\subsection{Data source}

We acquire the Global MRIO database and match the Eora input-output table with the African participants of FOCAC. Hence, we select a sample of 50 African countries in both the Eora database and the FOCAC, covering from the year 2000 to the year 
2015 (In the following parts, Africa refers to this 50-country sample.). These 50 sample countries include more than $90 \%$ of all African countries, among which are representative countries with close economic ties and trading relationship with China. The carbon-emission data comes from the World Bank Data Catalog (World Bank, 2018). Besides, we calculate the embodied carbon-emission intensity (total embodied carbon- emission per GDP) of Africa, China, the US, and the EU in constant 2005 USD. To fully elaborate the industrial structure of the embodied carbon transfer between China and Africa, we bracket the 26 sectors of the Eora input-output table into seven sectors: Agriculture, Mining, Food \& Wear, Manufacturing, Electricity, Construction, and Retail \& Other Services according to the Eora database and national economy industry categories (details see Table 1).

Table 126 fundamental industries and classifications of Eora Input-output Table

\begin{tabular}{ccc}
\hline Industry & Sector \\
\hline Agriculture & Agriculture \\
\hline Fishing & Mining \\
\hline Mining and quarrying & Food \& Wear \\
\hline Food and beverages & \\
\hline Textiles and wearing apparel & \\
\hline
\end{tabular}

Petroleum, chemical, and non-metallic mineral products

\begin{tabular}{|c|c|}
\hline Metal products & \multirow{4}{*}{ Manufacturing } \\
\hline Electrical and machinery & \\
\hline Transport equipment & \\
\hline Other manufacturing & \\
\hline \multicolumn{2}{|l|}{ Recycling } \\
\hline Electricity, gas, and water & Electricity \\
\hline Construction & Construction \\
\hline Maintenance and repair & \\
\hline \multicolumn{2}{|l|}{ Wholesale trade } \\
\hline \multicolumn{2}{|l|}{ Retail trade } \\
\hline \multicolumn{2}{|l|}{ Hotels and restaurants } \\
\hline Transport & Retail \& Other Services \\
\hline \multicolumn{2}{|l|}{ Post and telecommunications } \\
\hline \multicolumn{2}{|l|}{ Financial intermediation and business activities } \\
\hline \multicolumn{2}{|l|}{ Public administration } \\
\hline Education, health and other services & \\
\hline
\end{tabular}


Private households

Others

Re-export and re-import

\section{Result}

\subsection{Embodied carbon transfer between Sino-Africa, EU-Africa, and US-Africa}

Figure 1 (a) (b) describes the trend of total embodied carbon transfer, both direct and indirect, and the ratio of direct and indirect transfer to total transfer of China-Africa and Africa-China from 2000 2015 respectively. For Figure 1 (a), the direct transfer refers to the carbon-emission embodied in the final products that China exports to Africa for its demand. The indirect transfer refers to carbon-emission embodied in intermediate products from China to other countries which aim to complete final products and finally consumed by Africa. The research shows that the total embodied carbon-emission trans fer from China to Africa is significantly higher than that from Africa to China. Figure 1 (a) shows a rising trend of fluctuation, which reaches a peak in 2012. The total embodied carbon-emission transfer shoot up to about $24809 \mathrm{Kt}$, in which the direct transfer and indirect transfer is about $8543 \mathrm{Kt}$ and $16267 \mathrm{Kt}$ respectively. The amount of embodied carbon-emission transfer from Africa to China shows an increasing trend year by year. However, compared with China's embodied carbon-emission inflow to Africa, the amount of embodied carbon-emission transfer from Africa to China is small, reaching a maximum level of about $1000 \mathrm{Kt}$, much lower than the peak of embodied carbon transfer from China to Africa.

During the study period, China's indirect embodied carbon-emission transfer to Africa is the major part of total transfer. Its proportion shows a steady increase from 2004 to 2007 and finally stabilizes at more than $60 \%$ after 2007. Accordingly, the direct embodied carbon-emission from China to Africa declines gradually from 2004 to 2007 and drops below $40 \%$ after 2007 . On the contrary, the direct transfer from Africa to China occupies a large proportion. The amount of direct and indirect embodied carbon-emission transfer remains unchanged during the study period, 
whose proportion stabilizes at about $60 \%$ and $40 \%$ respectively. Therefore, we can see that China has made greater use of the global value chain to provide products to satisfy Africa's final demand. In this process, China indirectly undertakes a large amount of carbon-emission by meeting Africa's final demand to some extent.

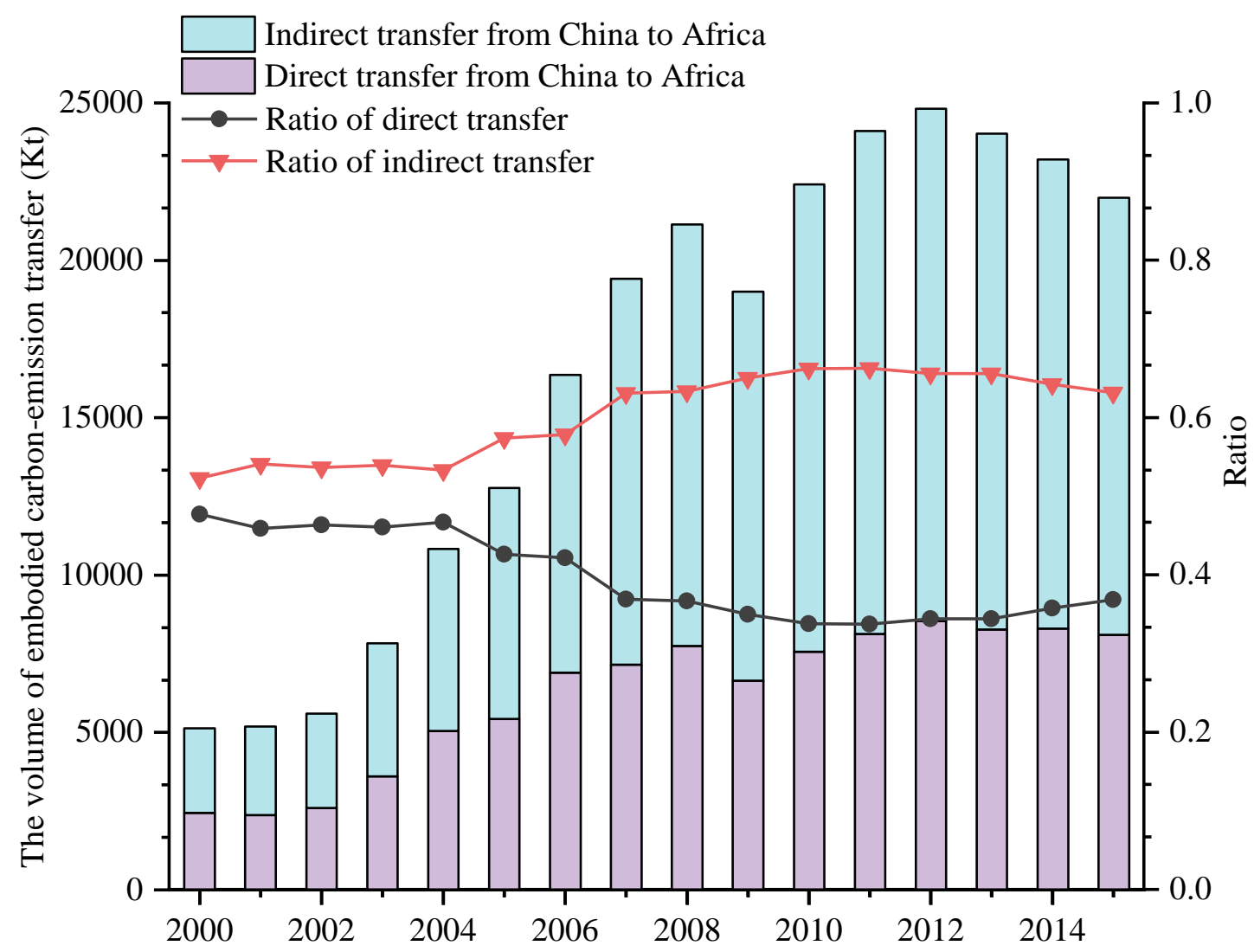

(a) 


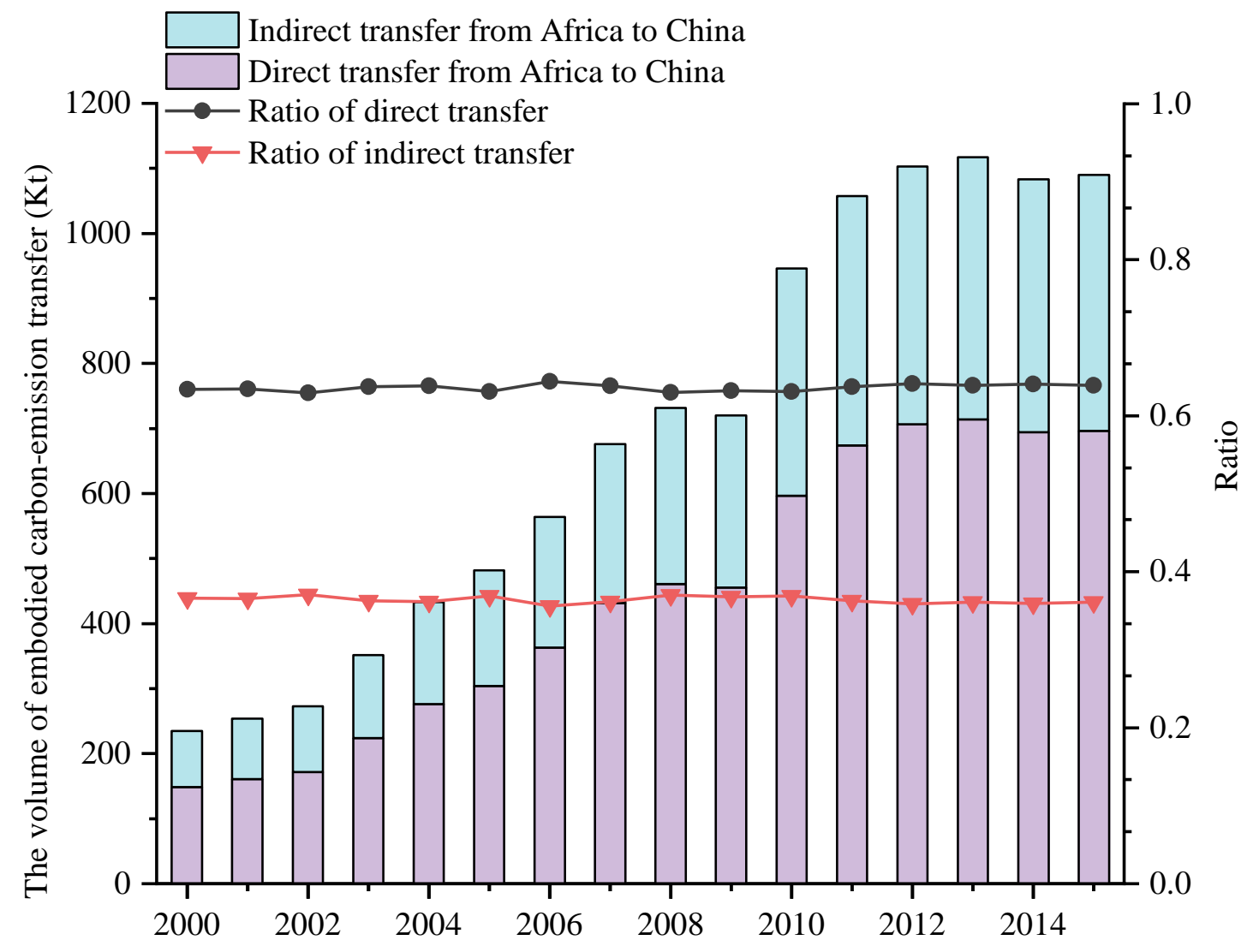

(b)

Figure 1The volume and ratio of direct and indirect embodied carbon transfer (a) from China to Africa; (b) from Africa to China.

In this section, we choose two major trading partners of Africa-EU and Africa-US for comparison and further discussion. Figure 2 (a) (b) depicts the embodied carbon transfer between Africa and the EU as well as Africa and the US respectively. EU has long been one of Africa's biggest trading partners, with its long-stand historical effect on the continent and geographic advantage. As an important export market, Africa plays a significant role in the EU's foreign trade. In 2011, Africa's commodity exports to the EU took up $30.31 \%$ of its total exportation ${ }^{1}$. Figure 2 (a) depicts a noteworthy amount of embodied carbon transfer between the EU and Africa during 2000 2015. Since 2000, the EU's net carbon outflow to Africa has always been positive, which declines drastically in 2009 but rises quickly again, and has been resting high since 2012. This trend is closely related to both parties' economic and trading status. EU exports have been hit hard by the economic crisis; thus, the collapse in EU's exports

\footnotetext{
${ }^{1}$ Data are from the report on World Economic and Trade Situation issued by the Ministry of Commerce of the People's Republic of China.
} 
to Africa may explain the decline in the embodied carbon-emission transfer, which has been exacerbated by falling demand for manufacturing along with factory closures and job losses. Net carbon transfer soars nearly double from 4055Kt in 2001 to $12936.4 \mathrm{Kt}$ in 2015. From 2000 to 2015, Africa's embodied carbon transfer to EU mounts by about $31 \%$. By comparison, the embodied carbon transfer between Africa and the US is relatively smaller, whilst the embodied carbon transfer from Africa to the US declines with fluctuation (see Figure 1 (b)). From the year 2000 to 2015, America's embodied carbon transfer to Africa climbs by $97.3 \%$, while that of Africa's drops by $20.9 \%$. The gap reverses sharply in 2011 - the US's embodied carbon transfer to Africa reverses from negative to positive. Between the year 2006 and 2007, Africa's embodied carbon transfer to the US slumps dramatically, as the gap narrows significantly, approaching zero in 2011. Before 2011, the US was a net importer of Africa's embodied carbon, in part elaborating the fact that a proportion of carbon-emission caused by the US's high level of consumption has been borne by African countries. Since 2011 the gap has reversed and is relatively small compared to that between Africa and China or the EU.

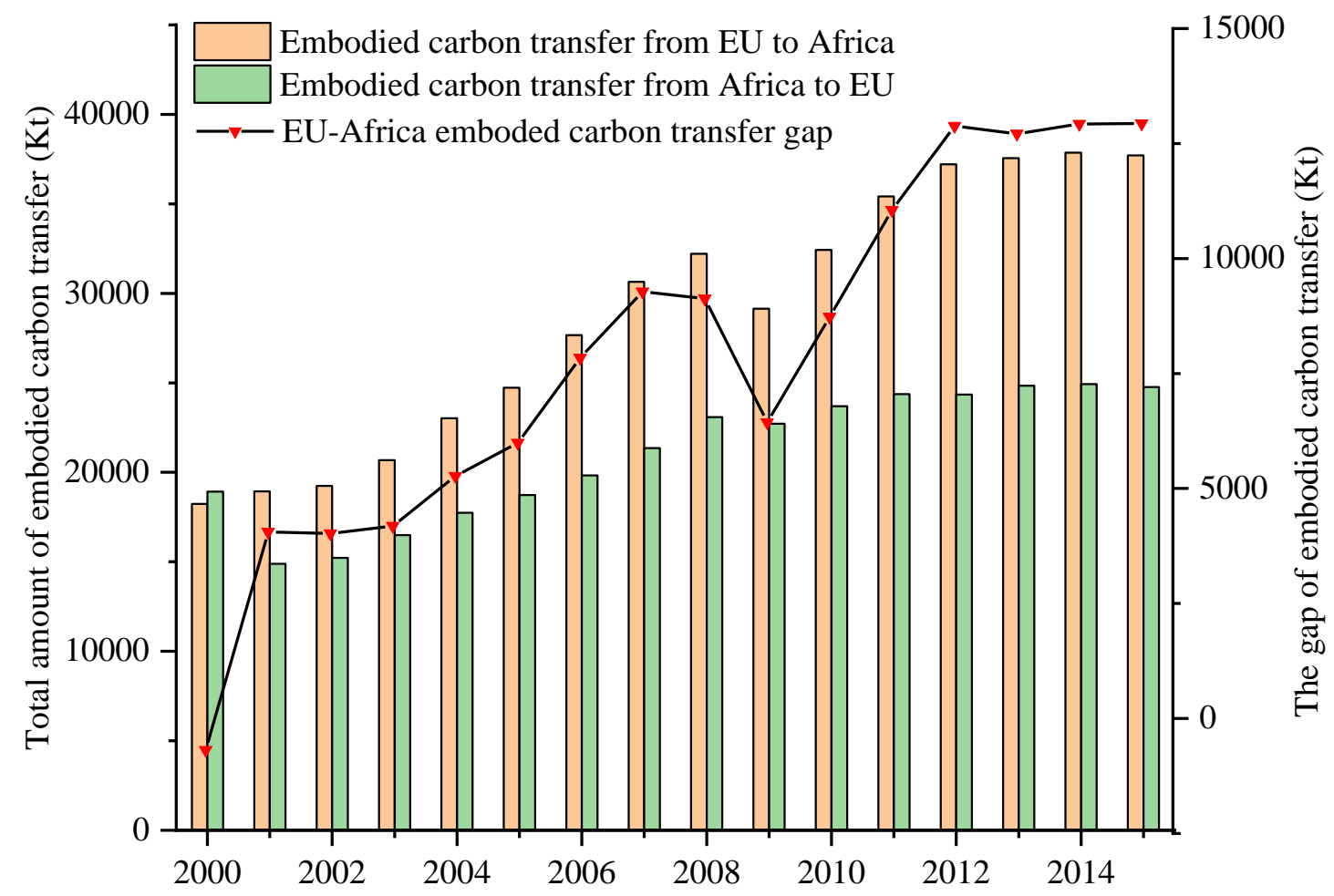


(a)

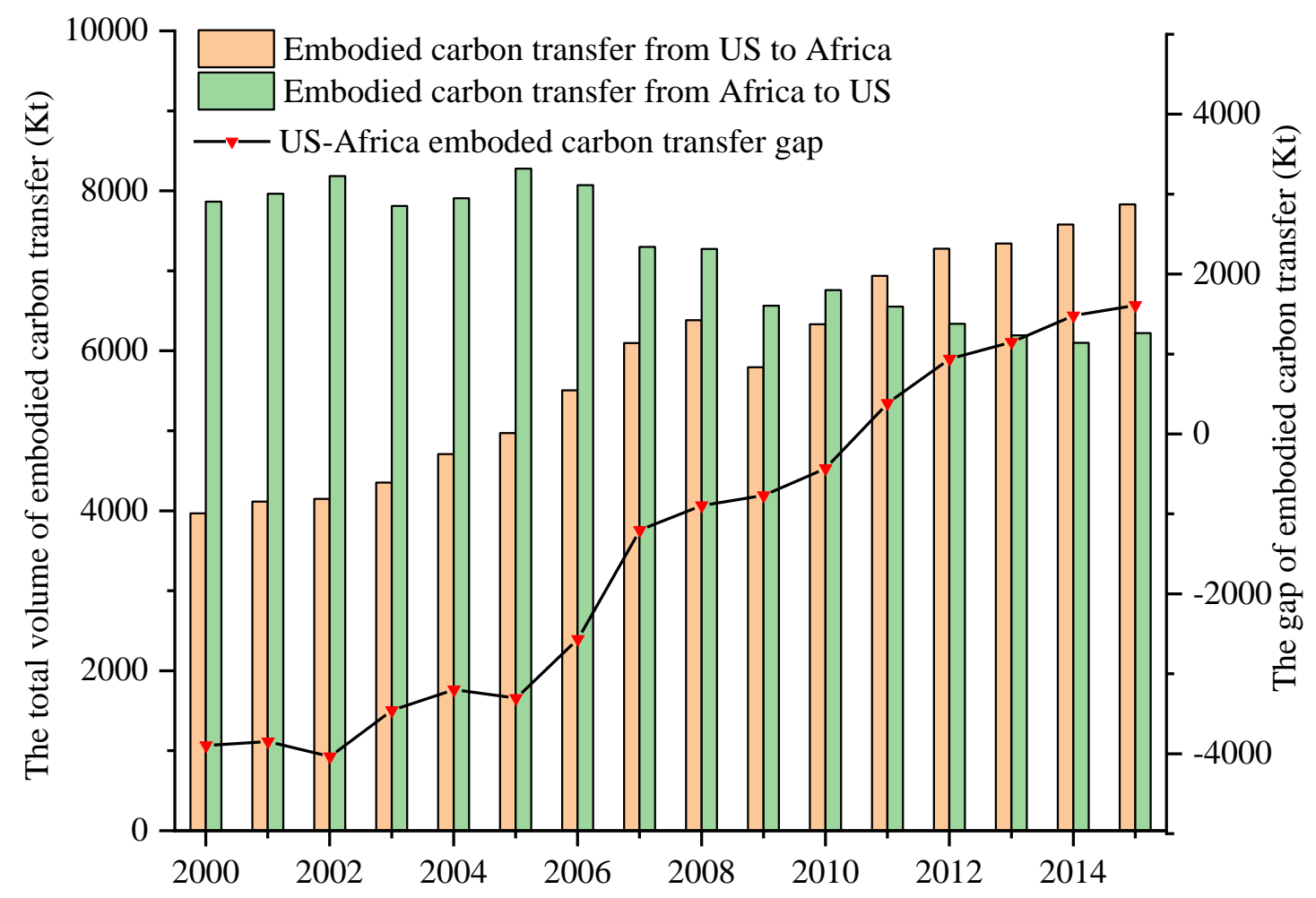

(b)

Figure 2 (a) (b) Sum and gap of embodied carbon transfer between Africa and EU/US

\subsection{Embodied carbon transfer by sector between China and Africa}

Figure 3 (a) (b) illustrates the sectoral contribution of embodied carbon transfer between China and the African participants in FOCAC respectively. China's sectoral distribution is structurally different from Africa's, and the amount ranges significantly from sector to sector in both countries. Among China's sectors, which export embodied carbon to Africa, the Manufacturing sector and the Food \& Wear sector take up a considerable proportion and contribute to the copious amount. In the year 2000, Manufacturing sector and Food \& Wear sector account for 50\% and $42 \%$ of the embodied carbon-emission transfer respectively, and for the following ten-odd years the two sectors contribute to around $90 \%$ in all every year, whilst the Manufacturing sector gradually eats up a larger share till mounting up to $70 \%$ in 2012 , and the ratio has rested at such level ever since. By contrast, the difference in embodied carbon-emission transferred to China between different sectors is comparatively insignificant, and the total amount is also relatively smaller. Though agricultural 
products are Africa's major exportation goods to China, yet due to its minor carbon-emission, the Agriculture sector has not taken up a dominant part in total carbon-emission.

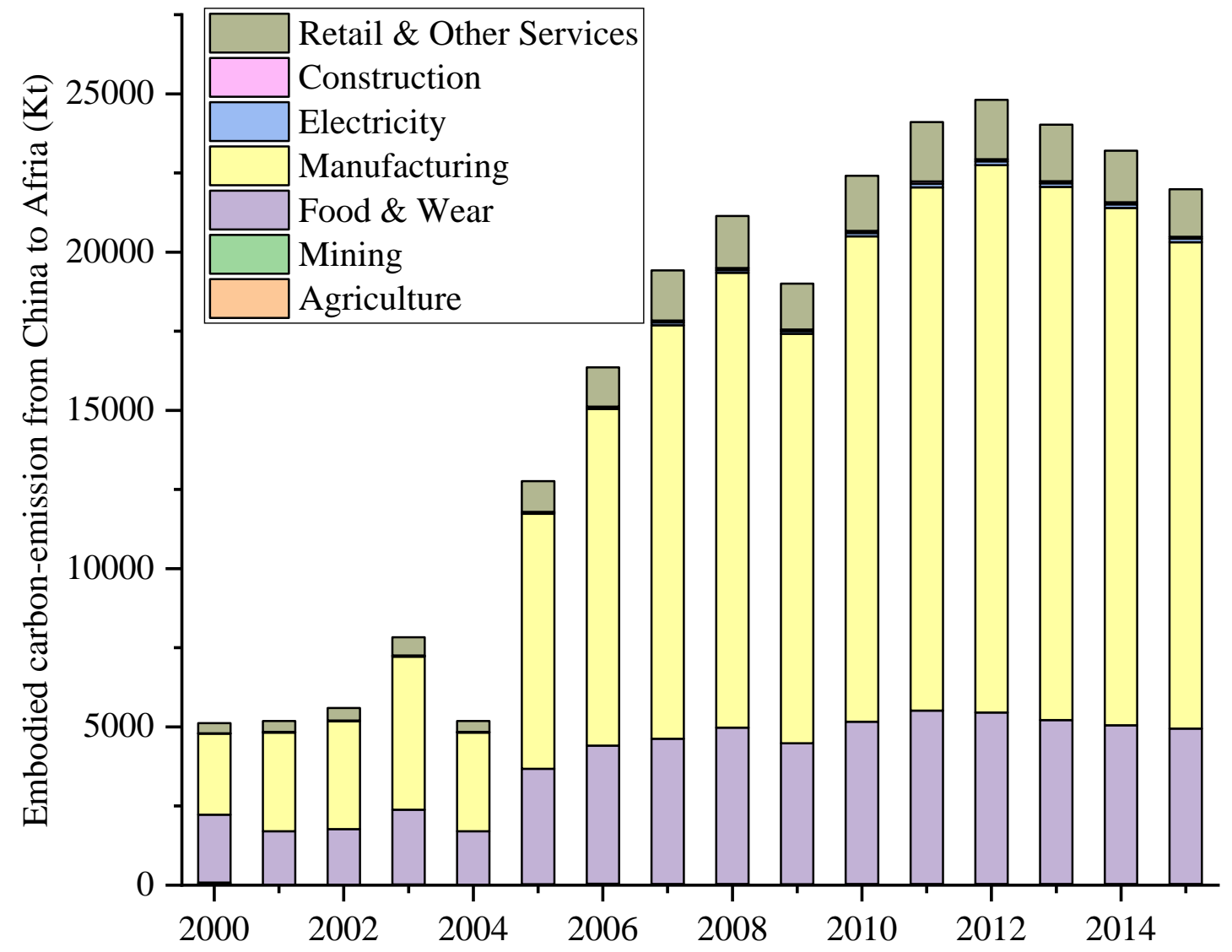

(a) 


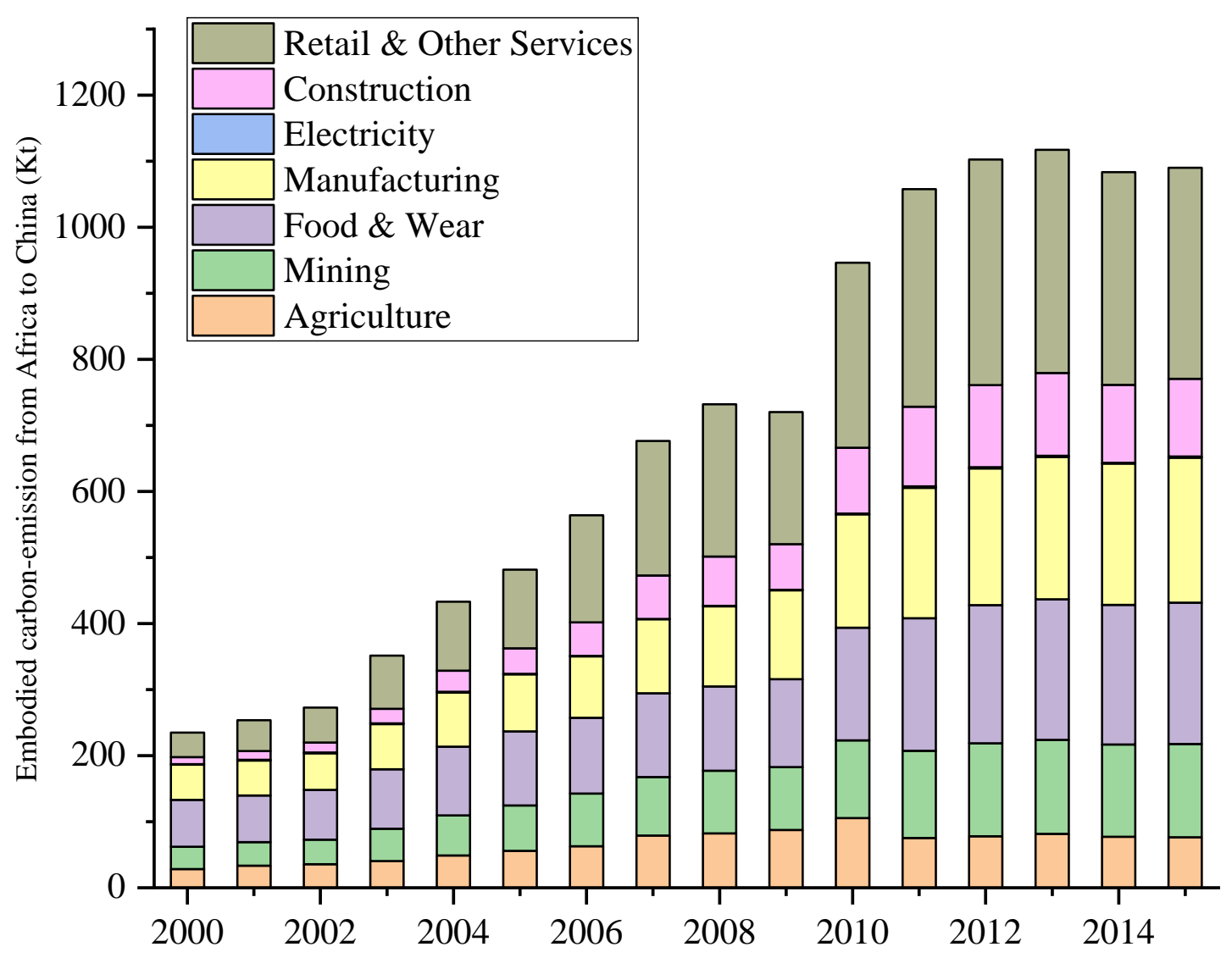

(b)

Figure 3 Sectoral contribution of embodied carbon transfer between China and Africa

\subsection{Embodied carbon transfer between China and African countries}

3.3.1 Sum and gap of embodied carbon transfer between China and all African countries

Table 3 reveals the 16-years' embodied carbon transfer between China and the African participants in FOCAC from 2000 to 2015 and ranks them from highest to lowest by embodied carbon transfer gap. On the recipient list of China's embodied carbon transfer, South Africa ranks first with a $65866.27 \mathrm{Kt}$ embodied carbon inflow, strikingly higher than its African peers. Nigeria, Egypt, Algeria, and Morocco follow by $43446.86 \mathrm{Kt}, 39888.67 \mathrm{Kt}, 26133.65 \mathrm{Kt}$, and $15602.32 \mathrm{Kt}$. As for Africa's embodied carbon transfer to China, South Africa also ranks first with a $4124.38 \mathrm{Kt}$ embodied carbon outflow. Other main embodied carbon export sources are Angola and Egypt, with a $2738.91 \mathrm{Kt}$ and $1056.51 \mathrm{Kt}$ outflow respectively. The rest African countries 
contribute to an insignificant amount of embodied carbon trans fer. In general, China's embodied carbon transfer to Africa notably exceeds that from Africa to China; in other words, the gap is not trivial. The different trade volume and trade structure between China and Africa contributes to such phenomena. Apart from Angola - the only net embodied carbon exporter to China, all other African countries are importers. South Africa, Nigeria, and Egypt are the three largest net importers, with a 61741.89Kt, 43060.24Kt, and 38832.16Kt net inflow respectively, while Angola transfers a $693.62 \mathrm{Kt}$ net outflow to China.

Table 2 The sum and gap of embodied carbon transfer between China and African countries,

2000-2015

\begin{tabular}{|c|c|c|c|c|c|c|c|}
\hline Country & $\begin{array}{c}\text { Embodied } \\
\text { carbon } \\
\text { outflow } \\
\text { from } \\
\text { China } \\
(\mathrm{Kt})\end{array}$ & $\begin{array}{l}\text { Embodied } \\
\text { carbon } \\
\text { inflow to } \\
\text { China } \\
\quad(\mathrm{Kt})\end{array}$ & $\begin{array}{c}\text { Embodied } \\
\text { carbon } \\
\text { transfer } \\
\text { gap }(\mathrm{Kt})\end{array}$ & Country & $\begin{array}{c}\text { Embodied } \\
\text { carbon } \\
\text { outflow } \\
\text { from } \\
\text { China } \\
\text { (Kt) }\end{array}$ & $\begin{array}{c}\text { Embodied } \\
\text { carbon } \\
\text { inflow to } \\
\text { China } \\
(\mathrm{Kt})\end{array}$ & $\begin{array}{c}\text { Embodied } \\
\text { carbon } \\
\text { transfer } \\
\text { gap }(\mathrm{Kt})\end{array}$ \\
\hline South Africa & 65866.27 & 4124.38 & 61741.89 & Gabon & 761.46 & 130.49 & 630.97 \\
\hline Nigeria & 43446.86 & 386.62 & 43060.24 & Togo & 607.20 & 6.06 & 601.14 \\
\hline Egypt & 39888.67 & 1056.51 & 38832.16 & Namibia & 596.54 & 14.26 & 582.28 \\
\hline Algeria & 26133.65 & 97.80 & 26035.85 & Malawi & 554.80 & 5.44 & 549.35 \\
\hline Morocco & 15602.32 & 311.56 & 15290.76 & Mozambique & 558.79 & 16.42 & 542.37 \\
\hline Tunisia & 8912.05 & 18.19 & 8893.86 & Burkina Faso & 513.21 & 1.85 & 511.36 \\
\hline Ghana & 6261.20 & 33.48 & 6227.72 & Djibouti & 496.98 & 5.31 & 491.68 \\
\hline Madagascar & 6136.50 & 26.49 & 6110.01 & Sierra Leone & 453.75 & 5.39 & 448.37 \\
\hline Ethiopia & 5757.18 & 118.95 & 5638.24 & Botswana & 441.90 & 2.95 & 438.94 \\
\hline Tanzania & 5040.01 & 201.21 & 4838.80 & Congo & 632.15 & 235.84 & 396.31 \\
\hline Kenya & 4400.01 & 114.15 & 4285.86 & Rwanda & 368.36 & 3.45 & 364.91 \\
\hline Mauritius & 3597.66 & 233.17 & 3364.49 & Cape Verde & 194.57 & 2.44 & 192.13 \\
\hline Libya & 3295.16 & 41.97 & 3253.18 & Gambia & 193.84 & 2.84 & 191.00 \\
\hline Senegal & 2850.73 & 97.42 & 2753.31 & Seychelles & 123.67 & 4.15 & 119.52 \\
\hline Cote dIvoire & 2817.65 & 121.79 & 2695.86 & Mauritania & 329.26 & 221.83 & 107.43 \\
\hline Cameroon & 2762.53 & 151.46 & 2611.08 & Eritrea & 109.26 & 3.03 & 106.24 \\
\hline DR Congo & 2482.23 & 5.55 & 2476.68 & Burundi & 94.50 & 2.98 & 91.52 \\
\hline Lesotho & 1608.23 & 2.13 & 1606.10 & Chad & 79.03 & 4.55 & 74.48 \\
\hline Uganda & 1373.41 & 28.23 & 1345.18 & $\begin{array}{l}\text { Central } \\
\text { African } \\
\text { Republic }\end{array}$ & 48.43 & 2.03 & 46.40 \\
\hline Mali & 1253.14 & 3.01 & 1250.13 & $\begin{array}{c}\text { Sao Tome and } \\
\text { Principe }\end{array}$ & 14.55 & 2.97 & 11.58 \\
\hline
\end{tabular}




\begin{tabular}{crrrcrrr}
\hline Zimbabwe & 1390.26 & 364.92 & 1025.35 & Liberia & 40.29 & 29.11 & 11.18 \\
Benin & 982.14 & 11.90 & 970.23 & Somalia & 11.99 & 0.97 & 11.03 \\
Guinea & 937.02 & 2.29 & 934.73 & Sudan & 11.19 & 0.36 & 10.83 \\
Zambia & 954.93 & 116.77 & 838.16 & South Sudan & 11.10 & 2.40 & 8.70 \\
Niger & 761.65 & 1.22 & 760.43 & Angola & 2045.30 & 2738.91 & -693.62 \\
\hline
\end{tabular}

3.3.2 Trend and sectoral contribution of embodied carbon transfer between China and four representative African countries

Figure 4 reveals the trend of embodied carbon transfer between China and Angola the only net exporter, South Africa, Nigeria, and Egypt - the three major net importers. Since 2002, China has been a net importer of embodied carbon from Angola, though around 2008, the gap narrows drastically, widens soon afterward, and narrows slightly again between 2012 and 2015. South Africa, Egypt, and Nigeria are the three significant recipients of China's embodied carbon transfer, and the trends of all three countries show a turning point in 2009 , where the declination ceases as the inflow starts mounting up, and recline back slowly from around 2012 to 2015. South A frica is the largest recipient, with an overwhelming proportion of embodied carbon inflow between 2000 and 2013, its trend also coordinating with the whole-picture trend between China and Africa. As for growth rate, Nigeria's embodied carbon inflow rises most notably, exceeding Egypt around 2010 and on par with South Africa around 2013. The net embodied carbon inflow of all three countries climbs up with fluctuation from 2000 to around 2012, decreases slightly between 2008 and 2009, and falls steadily from around 2012 to 2015 . 

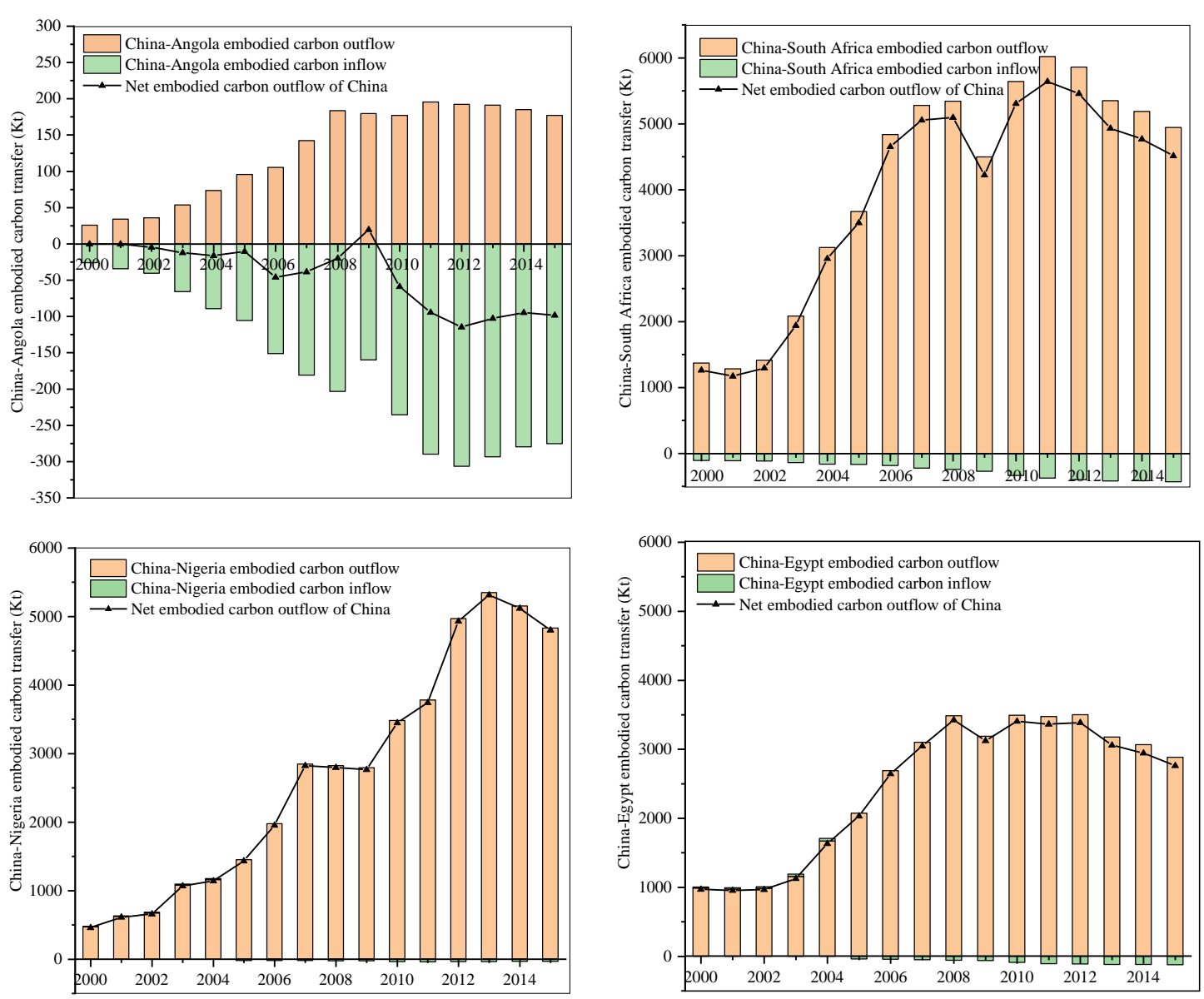

Figure 4 Bilateral volume and gap of embodied carbon transfer between China and the four African countries

Figure 5 shows the embodied carbon transfer by sector between China and Angola, South Africa, Nigeria, and Egypt. Among the moderate net embodied carbon transfer from China to Angola, the Textiles and wearing apparel sector ranks first, followed by Electrical and machinery, Transport equipment, and Other Manufacturing sectors. Between 2000 and 2009, the embodied carbon inflow of all sectors mounts gradually but declines with fluctuation after 2009. South Africa is the largest recipient of China's embodied carbon transfer, and the amount varies from sector to sector. The Electrical and machinery sector comes first, but its growth slows down after 2009, and even turns from positive to negative after 2011. The major sectoral recipients in Nigeria are the Electrical and machinery and Transport equipment sectors. The inflows of all sectors have been mounting before 2013 but dropping back steadily afterward. As for Egypt, the inflow of every sector climbs steadily between 2000 2009, but falls back with fluctuation after 2009; the Textiles and wearing apparel sector ranks with the highest embodied carbon inflow. 
Figure 6 shows the sectoral contribution of Angola's, South Africa's, Nigeria's, and Egypt's embodied carbon trans fer to China. Before 2010, the Mining sector has been the largest exporter of embodied carbon in Angola, while the net embodied carbon outflow of Angola's Transport sector fluctuates wildly, surpassing the Mining and quarrying sector around 2010 and becoming the most massive net embodied carbon exporter. The primary sources of Africa's embodied carbon transfer to China are the Electrical and machinery, Food and beverages, Transport, and Construction sector. The Food and beverages sector ranks first in embodied carbon outflow from 2000 to around 2003 but is later caught up by the Electrical and machinery sector, and the gap between the two sectors widens year by year. The major exporters of Nigeria's embodied carbon to China are the Transport and Mining and quarrying sector as well as the Construction sector, though both the outflows of the Transport sector and the Construction sector show a sharp turning point around 2011, whilst that from the Mining and quarrying sector mounts slowly. Egypt being one of the major producers of textiles, its Textiles and wearing apparel sector ranks first both in the sum of embodied carbon outflow and the growth rate, whilst the Agriculture sector comes second in total amount with a gradually lower growth rate. 


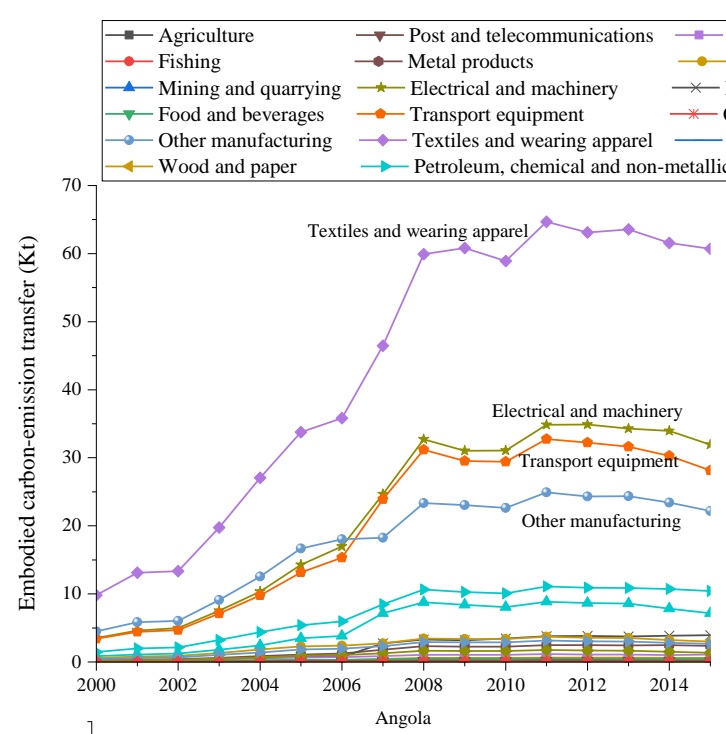

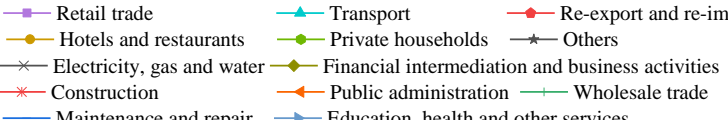

Maintenance and repair $\longrightarrow$ Education, health and other services
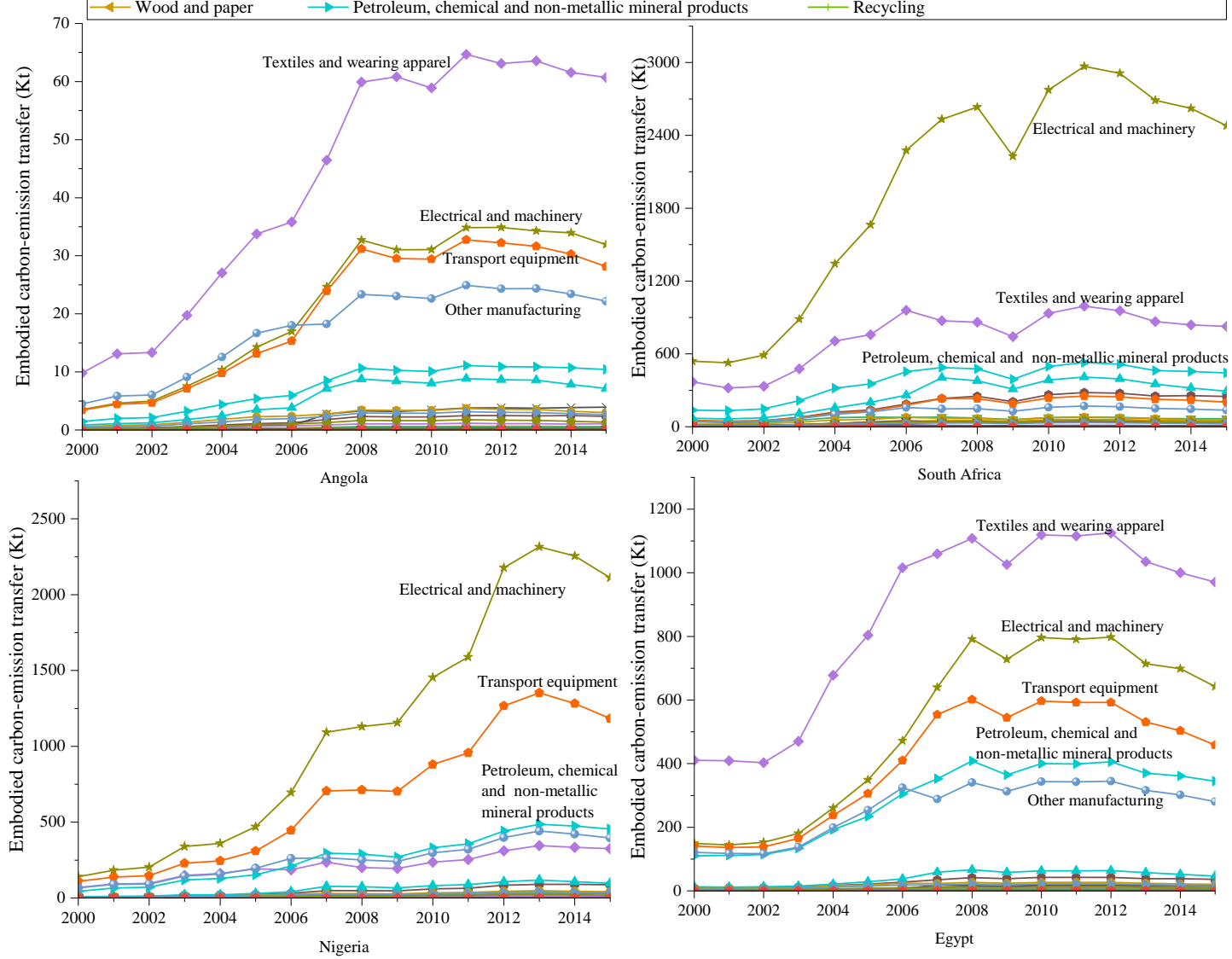

Figure 5 Sectoral contribution and tendency of China's embodied carbon transfer to the four African countries 

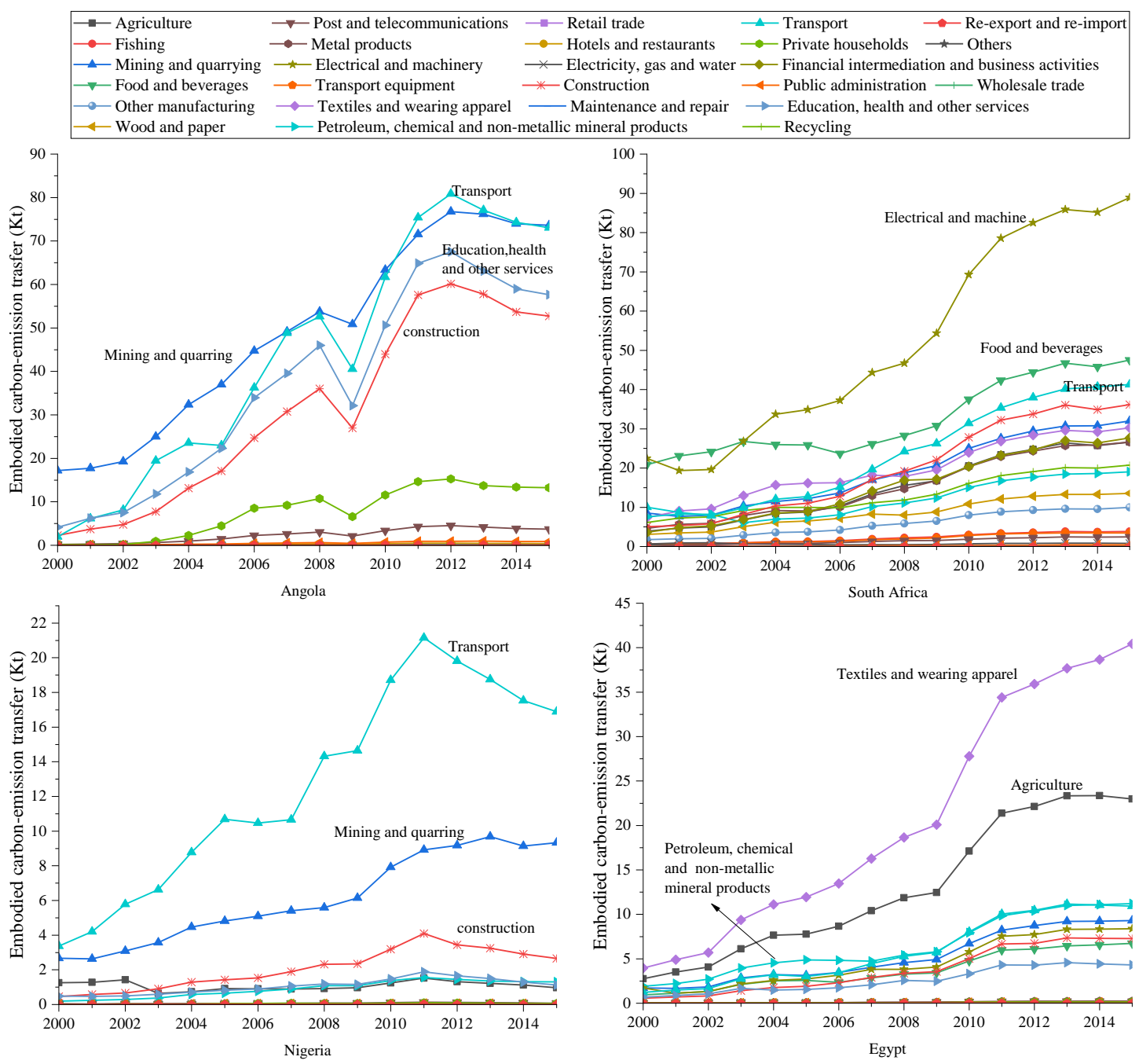

Figure 6 Respective sectoral distribution and tendency of the four African countries'embodied carbon transfer to China

\subsection{Embodied carbon-emission intensity}

In this paper, we calculate the carbon-emission intensity (total embodied carbonemission per GDP) of China and America from 2000 to 2015 in constant 2005USD respectively, and the average carbon-emission intensity of EU and that of the African participants of FOCAC (also in each nation's price in constant 2005USD). As can be seen in Figure 7, China always ranks first in carbon-emission intensity, closely followed by Africa. The intensities of the EU and the US are relatively lower and close. From 2000 to 2015, all four economies display a tendency in declining carbon-emission intensity. The embodied carbon-emission intensities of China, Africa, EU, and the US have decreased by $72 \%, 75 \%, 71 \%$, and $57 \%$ respectively. 
The embodied carbon-emission intensity of each sector shows a downward trend, but the structure differs between China and Africa. For China, the intensity of the Electricity sector is the highest, reaching $23.25 \mathrm{~kg} / \mathrm{USD}$ in 2003 and declining to 5.99 $\mathrm{kg} / \mathrm{USD}$ in 2015. Similarly, South Africa and Egypt have the peak in the Electricity sector, particularly South Africa, hitting $66.69 \mathrm{~kg} / \mathrm{USD}$ in 2002, and then falling all the time, hovering around $20 \mathrm{~kg} / \mathrm{USD}$. The Mining sector's intensity in Angola is highest, along with a significant decline. As for Nigeria, the intensity of the Mining sector is higher than the Electricity sector at first but it has been overtaken after 2004. The Electricity sector of the US and that of the EU have a higher embodied carbon-emission intensity than other sectors, but they are relatively lower compared to other economies.

A plummet in embodied carbon-emission intensity represents a boost in carbon-emission efficiency and a structural alternation in exportation. Though China's embodied carbon-emission intensity has been rather high, a declining tendency has emerged. The average embodied carbon-emission intensity of African countries is lower than that of China, also showing a decreasing tendency, which indicates a progressing economic development in Africa. 


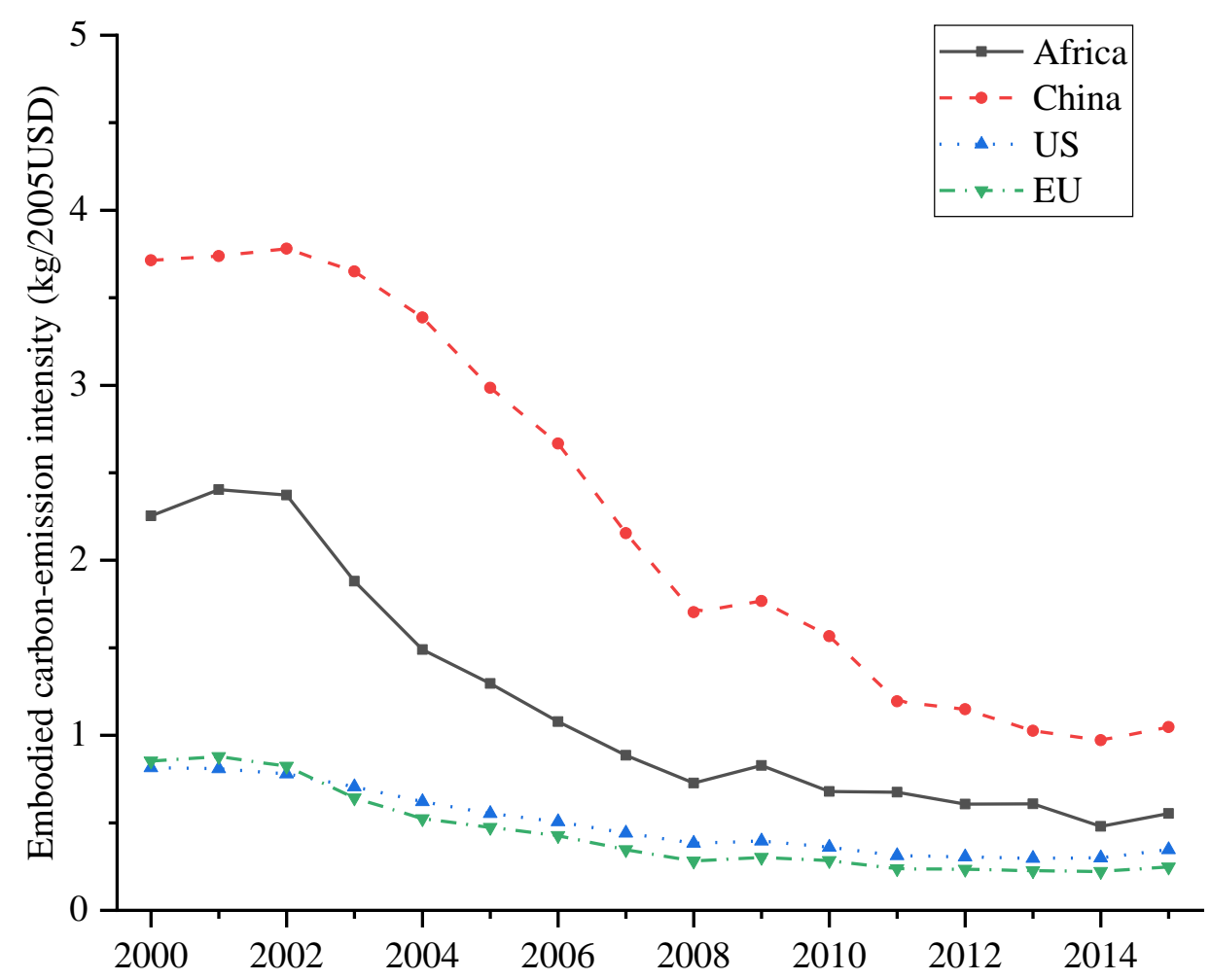

Figure 7 Embodied carbon-emission intensity of China, Africa, EU, US, 2000-2015

\section{Discussions}

\subsection{The link between embodied carbon-e mission transfer and trading structure between China and Africa}

There is a noticeable overlap between the primary recipients of China's embodied carbon transfer and China's major trading partners, and those with a brisk import-export trade with China also happen to have prominent trading gaps. Nigeria, South Africa, Egypt, and Angola are the four major economies and China's most intimate trading partners. Combing and summarizing trading data between China and Africa from 2000 to 2015 reveals that the ten largest African trading partners of China are South Africa, Angola, Nigeria, Egypt, Sudan, Algeria, Congo, Libya, Ghana, and Morocco. Generally, China's principal African trading partners share certain similarities such as bountiful resources in oil and ore or relatively large economic mass and advanced development. Figure 8 elaborates on the total import-export trades between China and Africa from 2000 to 2015. The bubbles represent the 50 African participants of FOCAC. Those beneath the $45^{\circ}$ line are China's net importers, while 
those above are net exporters. The size of the bubble represents the absolute volume of net import/export. We find that most of the African countries are China's net importers, with Nigeria and South Africa ranking first and second in trading volume. Nigeria and Egypt come top in trading deficit whilst Angola and South Africa in trading surplus. South Africa, Nigeria, and Egypt are China's three major trading partners, also the three major embodied carbon net importers. Angola, as China's second-largest African trading partner, on the other hand, is the largest net embodied carbon exporters among the African countries.

As the only developed country in Africa, South Africa stands out in terms of both embodied carbon outflows and inflows, owing to its high level of economic development and consumption. Nigeria, Egypt, Algeria, and Morocco, along with South Africa, are the top 5 countries with the best economic development. Compared with other Africa countries, their manufacturing industries are more developed, and they require an import of finished products and semi-finished products to meet their own needs. Angola is a famous oil producer and one of China's most important suppliers and partners in Africa, trading both petroleum products and manufactured goods. Thus, a significant bilateral embodied carbon-emission flow relationship is formed.

South Africa, Nigeria, and Egypt outstand in economic aggregate. Besides, with a relatively complete industrial structure, their service sectors have an absolute advantage over their agriculture and industry sectors. Such an industrial structure spurs a strong demand for finished products to meet the needs of production and living services. What distinguishes Angola from the three African countries mentioned above is its low level of economic development and industrial-oriented structure. Angola is rich in oil resources with energy and mineral products accounting for over $90 \%$ of its exports. It is a typical export-oriented economy and has maintained trade surplus for a long time, which matches a high degree of external dependence on oil of China. Therefore, Angola's economic development, industrial 
structure, and the trade structure between China and Ango la all determine that Angola is a net outflow country of embodied carbon-emission.

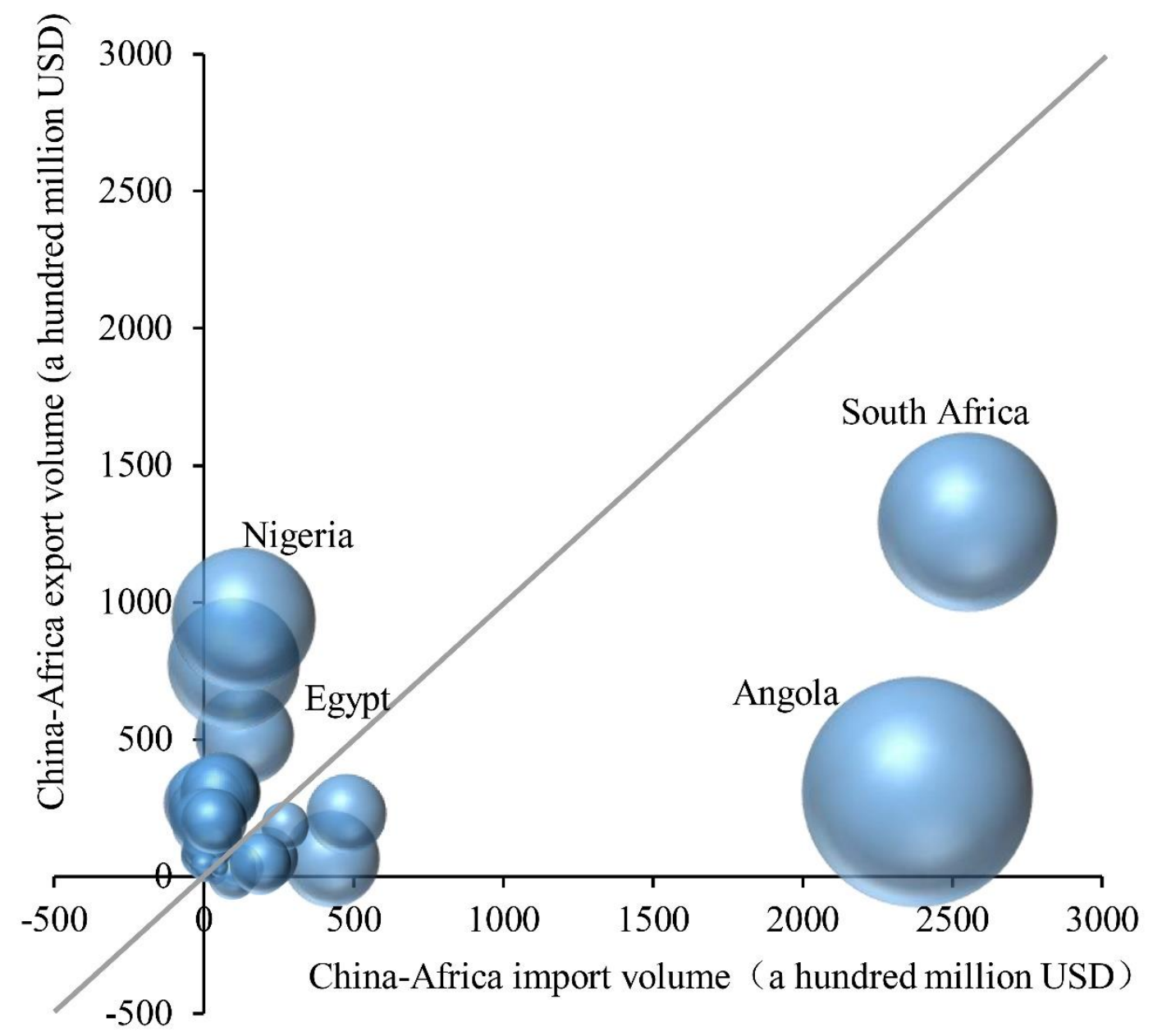

Figure 7 China-Africa import and export, 2000-2015

\subsection{Carbon-emission responsibility evaluation from the consumption view}

In the embodied carbon transfer link, China is the net exporter, which means that China burdens a much larger carbon-emission derived by Africa's consumption than that Africa bears derived by China's final demand. Meanwhile, behind the gigantic embodied carbon-emission gap lies a significant China-Africa trade deficit, indicating that China is not only bearing the carbon-emission cost of Africa's economic development and household consumption but also cutting economic benefits. Africa's growing exportation is closely related to the growth of its low-carbon primary exports to China. At the same time, its growing importation can be mainly attributed to the inflow of China's high-carbon manufactured goods, which in part elaborates how 
carbon-emission burden derived from Africa's consumption is transferred to its commodity supplier - China. Figure 9 depicts the change of net trade and net carbon transfer between the China-Africa from 2000 to 2015. Both net trade and net carbon transfer show two sharp turning points, one in 2008 and the other in 2012. Figure 9 visually illustrates the fact that trade between China and Africa had been in balance before 2008, while China's embodied carbon transfer to Africa had been increasing. Net trade becomes negative in 2008 but rises back in 2009 , utterly contrary to the change of net carbon transfer. Since 2008, there has been a distinctive negative relation between net trade and net embodied carbon transfer - when China's net trade export to Africa increases, its net embodied carbon outflow decreases. Between 2007 and 2014, China has been a net exporter in embodied carbon yet net importer of trade. In other words, China, while supplying Africans with multiple products via exportation, also shoulders the carbon-emission, which, from a consumption view, should be Africa's responsibility.

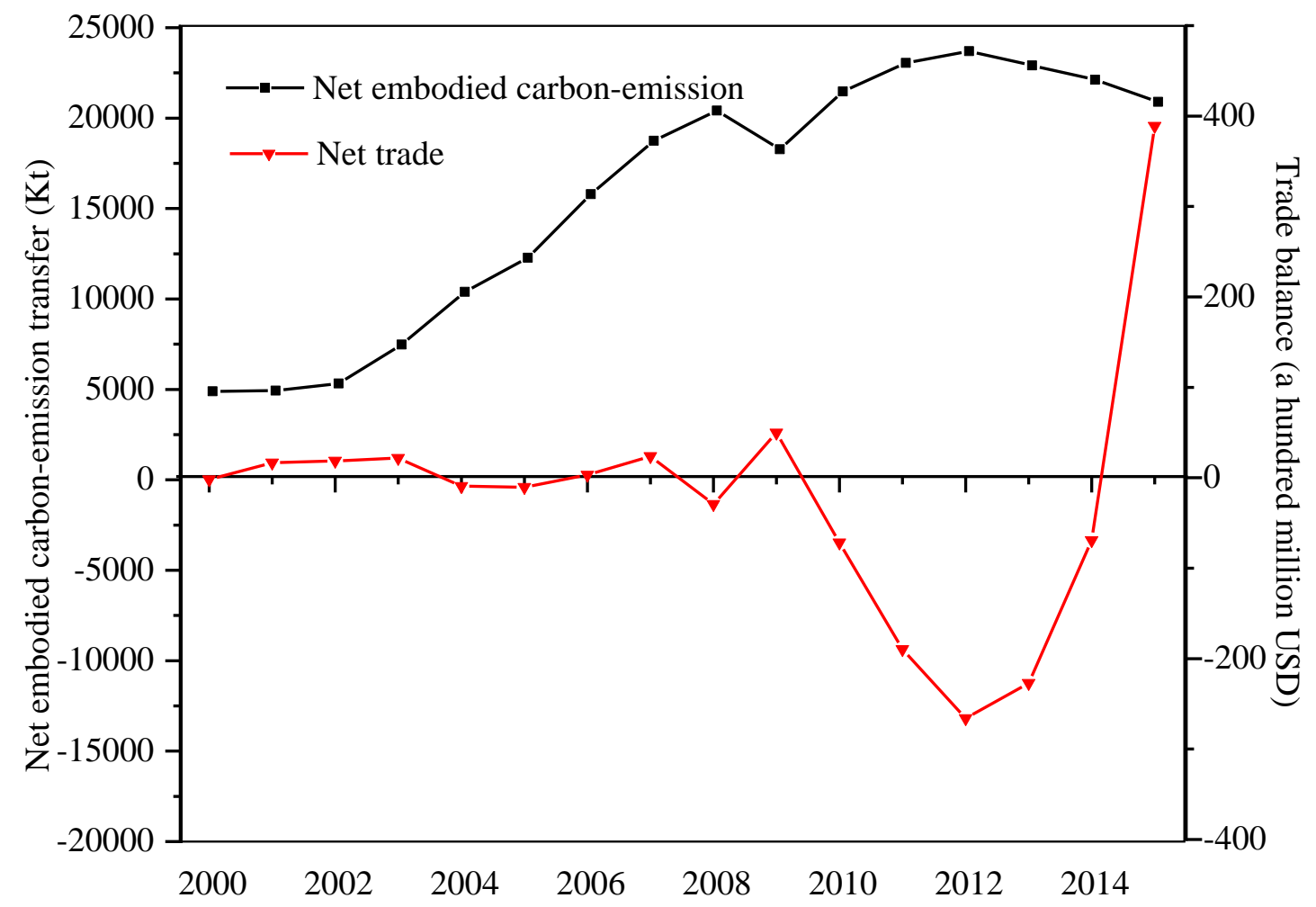

Figure 8 Net trade and net carbon transfer between China and Africa

\subsection{Review the embodied carbon-emission transfers between Sino-Africa,} EU-Africa, and US-Africa from their economic links 
Compared to the embodied carbon transfer between Africa and the EU and the US, China shoulders much carbon-emis sion derived by Africa's consumption while it does not put carbon-emission pressure on Africa. Africa's embodied carbon transfer to the EU is also considerable in size, far higher than its transfer to China, resulting in the fact that net carbon transfer between China and A frica exceeds that between Africa and the EU. It means that, even though the EU shoulders more carbon-emission derived from Africa's consumption than China, it also shifts an appreciable proportion of carbon-emission embodied in its consumption back to Africa. The US, on the other hand, has been a net embodied carbon importer before 2011, to some extent revealing the fact that part of its carbon-emission derived from high-level consumption has been the burden of African countries.

China, the EU, and America are all Africa's principal trading partners. Sino-Africa trade might grow fastest, yet it is the EU that always ranks top in bilateral trading volumes and plays a dominant role in Africa's international trades, owing to its historical influence on the continent and geographic advantages. Africa's exportation to the EU also takes up an epic proportion. As statistics have revealed, Africa's export commodities and trades to the EU took up 30.31\% in 2011 of its total exportation ${ }^{2}$. Africa-US trade, however, is slumping disastrously, due to the fact the US is self-reliant on oil and significantly cuts its importation from Africa. As elaborated in Figure 10, Sino-Africa, EU-Africa, and US-Africa embodied carbon transfer show a striking difference. The embodied carbon surplus between China and Africa is the result of a comparatively high embodied carbon export from China and a relatively low import, while despite the obvious embodied carbon surplus between the EU and Africa, carbon transfer from both sides is largest, compared to that between Sino-Africa and US-Africa. The US has become a net exporter of embodied carbon since 2011 , though the gap is minute.

Consequently, compared to the EU-Africa and US-Africa embodied

\footnotetext{
${ }^{2}$ Data are from the report on the World Economic and Trade Situation issued by the Ministry of Commerce of the People's Republic of China.
} 
carbon-emission flows, China has shouldered more carbon-emission derived from Africa's production and consumption via carbon-intensive commodity exports, while not shifting a proportional carbon-emission from its consumption back to Africa. As for Africa, with its loose economic base and low-level manufacturing capacity, economic development entails importation from better-developed regions such as China, the EU, and the US, while a step-up production by local or foreign investment. The latter will inevitably lead to an increase in local carbon-emission. The Sino-Africa trade not only provides financial support to Africa's economic development but also shoulders a certain degree of carbon-emission derived from Africa's consumption, both reducing the carbon-emission pressure of the continent.

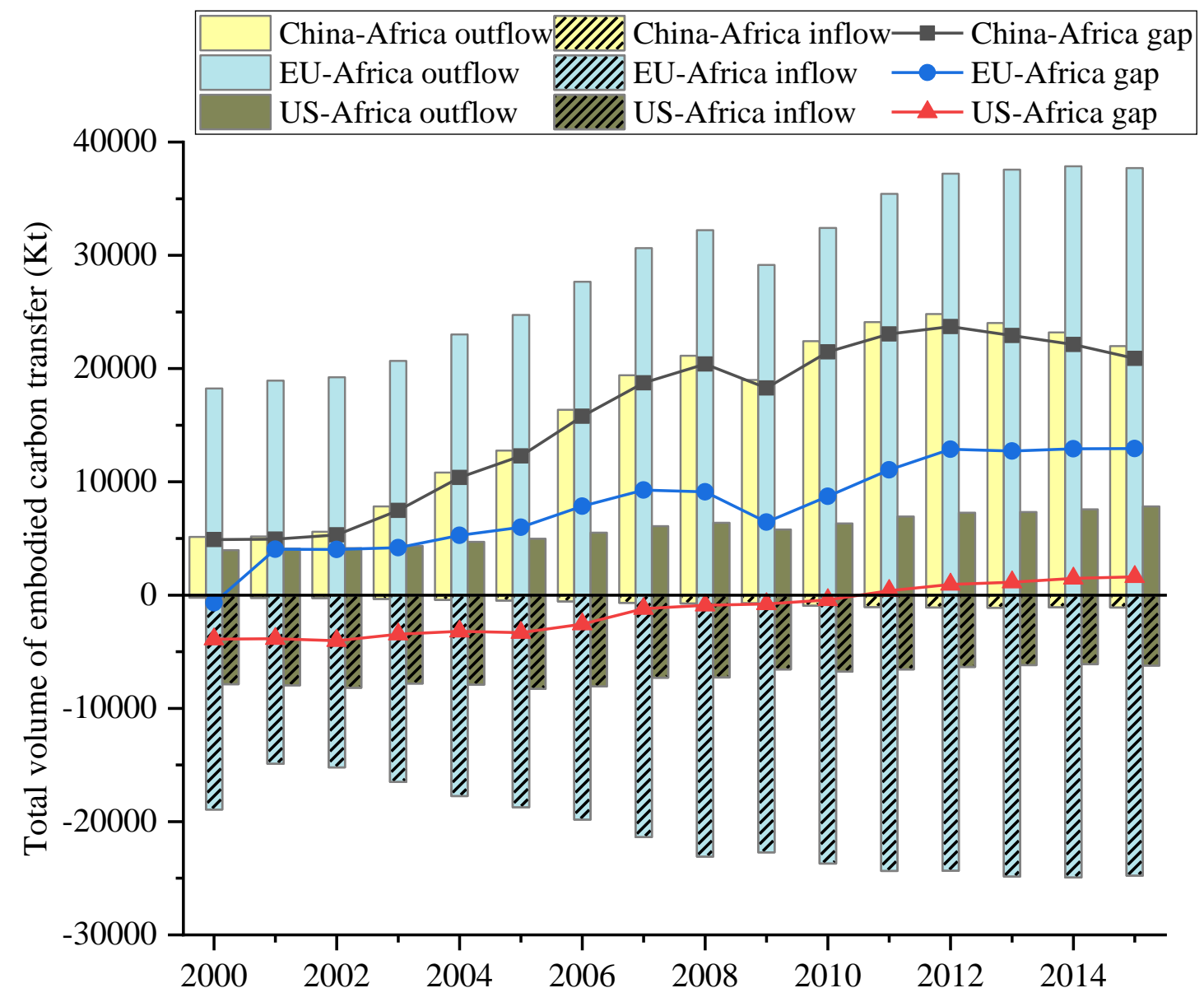

Figure 9 Embodied carbon transfer between Africa and China, EU, US

\subsection{Reevaluate the sectoral contribution of bilateral trade to economic growth between China and Africa}


Structurally, the sectoral difference of embodied carbon transfer between China and Africa is the product of difference in trading structure, which, in a way, reflects the complementarity of the two economies. Hampered by its loose economic base and low-level manufacturing, traditional and low-value-added consumer goods play a dominant role in Africa's Manufacturing. At the same time, industrial development involves the mass import of manufactured and semi-manufactured products to meet the enormous demand for both production and consumption. China is the biggest textile producer and exporter around the globe with relatively matured manufacturing capacity, especially in textiles, whose exportation soars in recent years. A majority of China's export to Africa is labor and resource-intensive commodities, mainly in the Food \& Wear, Manufacturing, and other few sectors. China imports primary products such as crude oil and iron ore from Africa to sustain its production and exports manufactured goods to satisfy Africa's consumption and economic development needs. Hence, China and Africa's exporting structures strongly complement each other, and trading coord ination will be crucial to both parties' development. China and Africa have very promising potentials in further cooperation in textiles, non-metallic mineral products, and other industries. Figures 10 and 11 illustrate respectively the Sino-Africa trade's contribution to both China's GDP growth and the African countries' (calculated from Sino-Africa trading data and the proportion final demand sectors in the Eora input-output table). As shown in Figure 10, both the Manufacturing and Food \& Wear export to Africa contribute substantially to China's GDP. From 2000 to 2015, each sector's value contribution to China's GDP roses, and the absolute growth rate of the two principal sectors - Food \& Wear and Manufacturing - is $16.7 \%$ and $25 \%$ respectively. In relative magnitude, each sector's contribution differs, as the Food \& Wear sector's percentage declines constantly from $33.2 \%$ in 2000 to $25.8 \%$ in 2015 , while the Manufacturing sector mounts steadily from $53.6 \%$ in 2000 to $61.2 \%$ in 2015 . As for the economic contribution of Africa's export sectors (see Figure 11), Retail \& Other Services, Manufacturing, and Food \& Wear come first, second and third, and both Food \& Wear and Manufacturing sector's percentage climb steadily with a $24.9 \%$ and $20.8 \%$ growth rate respectively. 


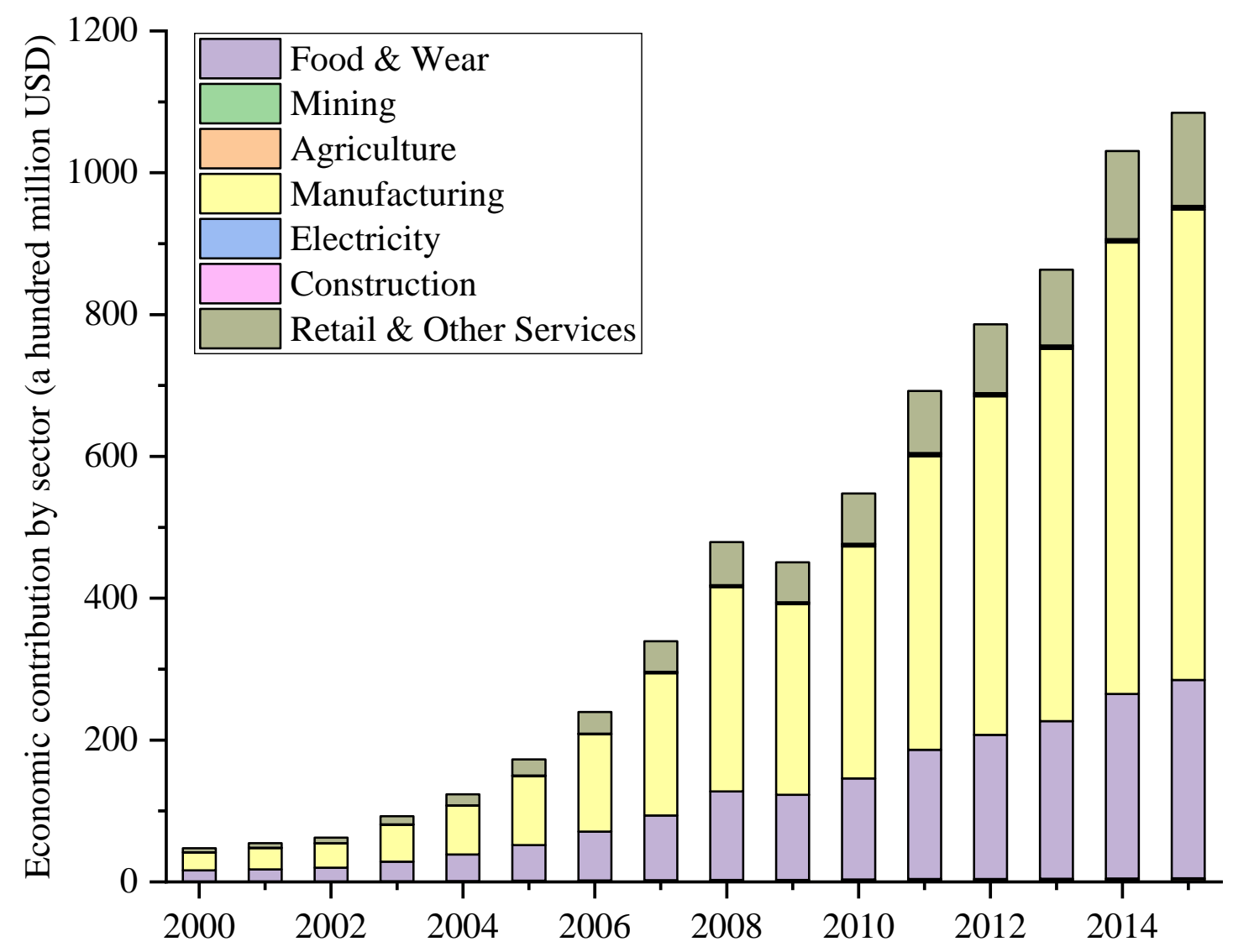

Figure 10 Sectoral contribution of Sino-Africa export trade to China's GDP growth

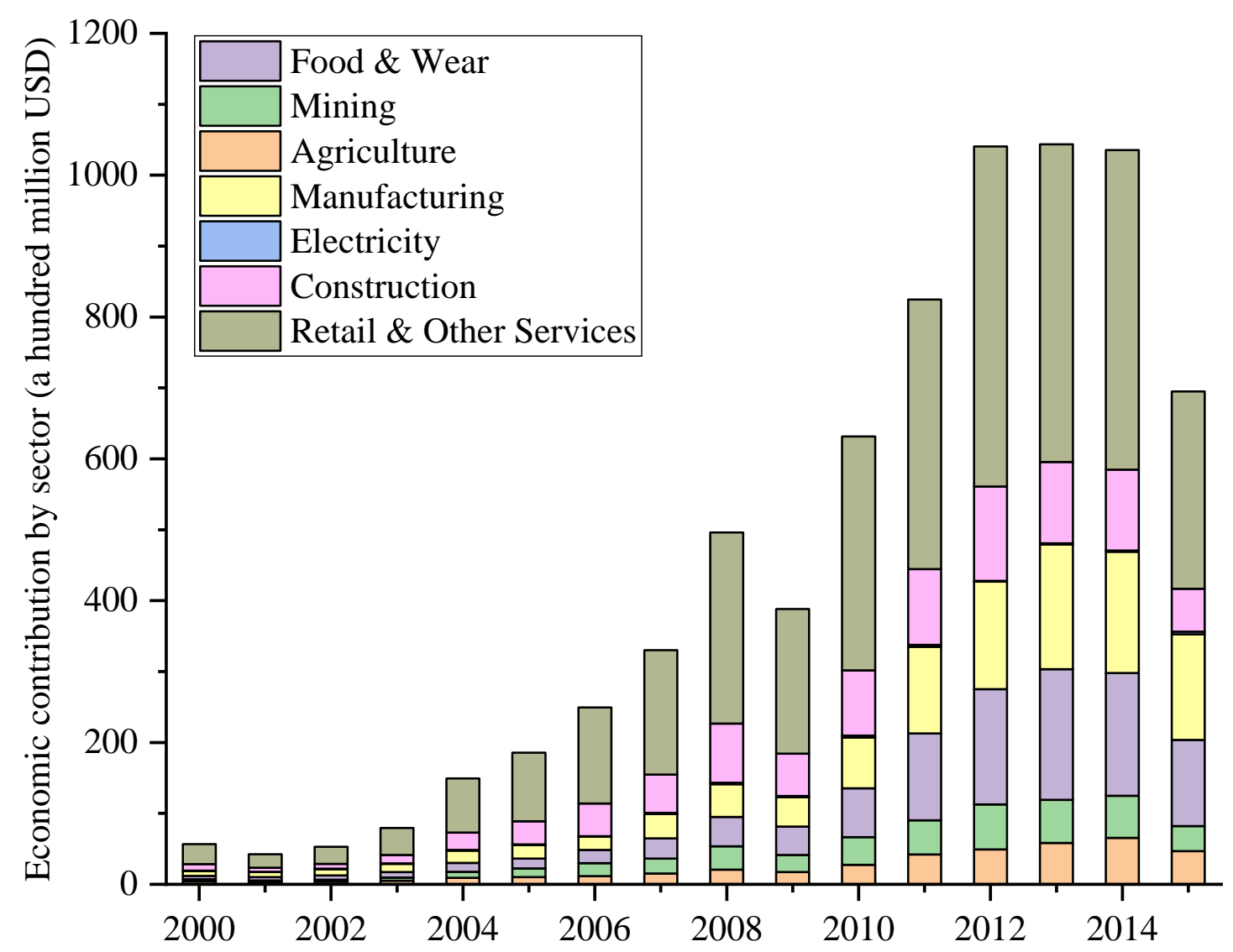

Figure 11 Sectoral contribution of Sino-A frica import trade to Africa's GDP growth 


\section{Conclusion and policy implications}

Since the foundation of the FOCAC, the trading link between China and Africa has been strengthening over time, which, to some extent, has affected production and carbon-emission on both parties. To comprehensively evaluate the Sino-Africa trade's influence on China's and Africa's carbon-emission, we conduct a systematic quantitative analysis on Sino-Africa trade's impact on China's and Africa's carbon-emission since the foundation of the FOCAC, applying the MRIO method and covering fifteen years study period. Our results show that between 2000 and 2012, the sum and net embodied carbon transfer between China and Africa climb up with fluctuation while declining steadily after 2012. South Africa, Nigeria, and Egypt are the three top embodied carbon recipients, while Angola is the only net embodied carbon exporter. Compared to the embodied carbon transfer between Africa and the EU and that with the US, the gap between China and Africa is the widest. For Africa, both China and the EU are embodied carbon exporters, whilst the US has been a net importer before 2011. Moreover, between 2000 and 2012, the embodied carbon-emission intensity of China, the African countries, the EU, and the US have all declined. China's and Africa's embodied carbon transfer differ greatly in sectoral distribution, and the emission magnitude varies magnificently from sector to sector.

Our main conclusions are as follows:

(1) From the consumption view, China plays the part of a net embodied carbon exporter. It means that China has shouldered more carbon-emission derived from Africa's consumption than Africa has shouldered that derived from China's consumption.

(2) Compared to the EU-Africa and US-Africa embodied carbon-emission flows, China has shouldered more carbon-emission derived from Africa's consumption, while not shifting a proportional carbon-emission from its consumption back to Africa. 
(3) The structural difference in both the Sino-Africa trade and the embodied carbon transfer sectors can, in part, reflect the complementarity between the two parties. The current trading status and carbon transfer trend are the product of China's and Africa's comparative advantages and economic development needs.

(4) Since the foundation of the FOCAC, the declining embodied carbon-emission intensity of both parties reveals an improvement of both parties' embodied carbon-emission structure and efficiency. Moreover, it is a solid proof of the positive influence China and Africa have played on carbon-emission efficiency.

For China, our economic reform has explored deeper waters with a compelling need for structural reform. As China's industrial structure upgrades, our major exports to Africa have diverted gradually from primary industrial products to mechanical and electrical products, textiles, and high-tech products. Meanwhile, both the quality and technical content of commodities have improved by leaps and bounds ${ }^{3}$. With the industrialization progress and the establishment of a value-added chain, Africa has acquired better export competence. Its trading commodities have altered to some extent, with an increase in textile and manufacturing products. Africa's industrial manufactured goods such as iron, chemical fertilizer, and primary electronic products pour into China and play a more and more critical role in the African economy. Based on these phenomena, we believe that the China-Africa embodied carbon-emission gap will be narrowed in the future.

To achieve the goal of low-carbon development and high-efficiency trade cooperation, there is still much room for improvement in the industrial and trad ing structure of China and Africa. We propose three suggestions on where and how China and Africa should cooperate in the future:

(1) China and Africa should cling to the intimate trading touch and utilize its positive impact on reducing the carbon-emission intensity of both parties and further

\footnotetext{
${ }^{3}$ http ://www. yearbook. org. cn/
} 
optimize its industrial and trading structure and attain its carbon-emission efficiency goal.

(2) Comprehensively, trading structure optimization entails cross-regional cooperation and rational, whole-picture planning. Both China and Africa should lay more emphasis on enhancing its trading qualities, discerning low-carbon, and competitive industries, promoting cooperation in trades and low-carbon technology, building an environmentally-friendly value chain and a sustainable, long-term trading relationship, and further promoting low-carbonized trade.

(3) Regionally, both China and Africa should make full use of their comparative advantages and raise their awareness of emission cuts and enhance carbon-emission efficiency.

1) For China, we doubtlessly have a more reliable economic and financial base to enhance our carbon-emission efficiency and cut emissions. With the New Normal of economic development, economic transformation and industrial structure upgrade are inevitable. Hence, China must optimize its industrial structure, reduce carbon-emission intensity, promote exportation structure, and raise the proportion of medium - and high-level manufacturing in total exportation.

2) For Africa, its unsolid economic base and immature infrastructure mean that manufacturing development and taking an active part in the global value chain division by utilizing its comparative advantage will be crucial to a cut in high-carbon manufactured goods and a boost in the economy. Africa is in dire need of manufacturing improvement and reduces its reliance on manufactured and semi-manufactured goods.

\section{Acknowledgments}

This research is jointly supported by the Natural Science Foundation of China (grant No. 71673014, No. 71973008, and No. 41701135), and the Philosophy and 
Social Sciences Major Project Fund of the Ministry of Education (grant No. 18JZD029).

\section{Reference}

Adisu, K., Sharkey, T., Okoroafo, S.C., 2010. The impact of Chinese investment in Africa. International Journal of Business and Management. 5(9). https $/ /$ doi.org/10.5539/ijbm.v5n9p3

Al-mulali, U., Sheau-Ting, L., 2014. Econometric analysis of trade, exports, imports, energy consumption and $\mathrm{CO} 2$ emission in six regions. Renewable and Sustainable Energy Reviews. 33, 484-498. https://doi.org/10.1016/j.rser.2014.02.010

Arce, G., López, L.A., Guan, D., 2016. Carbon emissions embodied in international trade: The post-China era. Applied Energy. 184, 1063-1072. https:/doi.org/10.1016/j.apenergy.2016.05.084

Baliamoune-Lutz, M., 2011. Growth by destination (where you export matters): Trade with China and growth in African countries. African Development Review. 23(2), 202-218. https://doi.org/10.1111/j.1467-8268.2011.00281.x

Berthelemy, J.C., 2011. Working paper 129 - China's engagement and aid effectiveness in Africa. Working Paper Series.

Broadman, H.G., Isik, G., 2006. Africa's silk road: China and India's new economic frontier (Washington, DC: World Bank). https://oi.org/10.1596/978-0-8213-6835-0

Cadarso, M.-Á., Monsalve, F., Arce, G., 2018. Emissions burden shifting in global value chains - winners and losers under multi-regional versus bilateral accounting. Economic Systems Research. 30, 439-461. https $/ /$ doi.org/10.1080/09535314.2018.1431768

Chen, Z.M., Chen, G.Q., Chen, B., 2010. Embodied carbon dioxide emissions of the world economy: A systems input-output simulation for 2004. Procedia Environmental Sciences, International Conference on Ecological Informatics and Ecosystem Conservation (ISEIS 2010). 2, 1827-1840. https:/doi.org/10.1016/j.proenv.2010.10.194

Chen, G., Wiedmann, T., Wang, Y., Hadjikakou, M., 2016. Transnational city carbon footprint networks - Exploring carbon links between Australian and Chinese cities. Applied Energy. 184, 1082-1092. https://doi.org/10.1016/j.apenergy.2016.08.053 
Choi, T., 2015. Understanding environmental responsibility of cities and emissions embodied in trade. Economic Systems Research. 27, 133-153. https:/doi.org/10.1080/09535314.2015.1012638

Davies, M., 2008. How China delivers development assistance to Africa. Centre for Chinese Studies, University of Stellenbosch.

Dietzenbacher, E., Pei, J., Yang, C., 2012. Trade, production fragmentation, and China's carbon dioxide emissions. Journal of Environmental Economics and Management. 64, 88-101. https://doi.org/10.1016/j.jeem.2011.12.003

Eisenman, J., 2012. China-Africa trade patterns: Causes and consequences. Journal of Contemporary China. 21(77): 793-810. https:/doi.org/10.1080/10670564.2012.684964

Eora, 2018, http:/worldmrio.com/eora26/

FAO, 2018. Food and Agriculture Organization of the United Nations. http://www. fao.org/faostat/en/\#home.

Fernández-Amador, O., Francois, J.F., Oberdabernig, D.A., Tomberger, P., 2017. Carbon dioxide emissions and economic growth: An assessment based on production and consumption emission inventories. Ecological Economics. 135, 269-279. https:/doi.org/10.1016/j.ecolecon.2017.01.004

Foster, V., 2009. Building Bridges: China's Growing Role as Infrastructure Financier for Sub-Saharan Africa, Trends and Policy Options, No.5 (Washington, DC: World Bank: Public-Private Infrastructure Advisory Facility). https://oi.org/10.1596/978-0-8213-7554-9

Geng, Y., Tian, X., Sarkis, J., Ulgiati, S., 2017. China-USA trade: Indicators for equitable and environmentally balanced reso urce exchange. Ecological Economics. 132, 245-254. https://doi.org/10.1016/j.ecolecon.2016.11.008

Giovannettia, G., Sanfilippo, M., 2009. Do Chinese exports crowd-out African goods? An econometric analysis by country and sector. European Journal of Development Research Special Issue. https://doi.org/10.1057/ejdr.2009.20

Han, M.Y., Chen, G.Q., 2018. Global arable land transfers embodied in Mainland China's foreign trade. Land Use Policy. 70, 521-534. http://dx.doi.org/10.1016/j.landusepol.2017.07.022

Han, M.Y., Yao, Q.H., Liu, W.D., Dunford, M., 2018. Tracking embodied carbon flows in the Belt and Road regions. Journal of Geographical Sciences. 28, 
Hertwich, E.G., Peters, G.P., 2009. Carbon footprint of nations: A global, trade-linked analysis. Environment Science and Technology. 43, 6414-6420. https:/doi.org/10.1021/es803496a

Hu, Y., Lin, J., Cui, S., Khanna, N. Z., 2016. Measuring urban carbon footprint from carbon flows in the global supply chain. Environmental Science \& Technology. 50, 6154-6163. https://doi.org/10.1021/acs.est.6b00985

Huang, S., An, H., Viglia, S., Buonocore, E., Fang, W., Ulgiati, S., 2017. Revisiting China-Africa trade from an environmental perspective. Journal of Cleaner Production. 167, 553-570. https://doi.org/10.1016/j.jclepro.2017.08.171

IEA, International Energy Agency, 2018, https $/ /$ www.iea.org/.

Ji, X., Long, X., 2016. A review of the ecological and socioeconomic effects of biofuel and energy policy recommendations. Renewable and Sustainable Energy Reviews. 61, 41-52. https://doi.org/10.1016/j.rser.2016.03.026

Ji, X., Yao, Y., Long, X., 2018. What causes PM2.5 pollution? Cross-economy empirical analysis from socioeconomic perspective. Energy Policy. 119, 458-472. https:/doi.org/10.1016/j.enpo1.2018.04.040

Ji, X., Han, M., Ulgiati, S., 2020. Optimal allocation of direct and embodied arable land associated to urban economy: Understanding the options deriving from economic globalization. Land Use Policy. 91, 104392. https:/doi.org/10.1016/j.landusepo1.2019.104392

Jefferis, K., 2012. Africa needs China's positive investment. |Economy |chinadaily.com.cn.

Kaplinsky, R., Morris, M., 2008. Do the Asian drivers undermine export-oriented industrialization in SSA? World Development. 36(2), 254-273. https:/doi.org/10.1016/j.worlddev.2007.06.007

Kolstad, I., Wiig, A., 2011. Better the devil you know? Chinese foreign direct investment in Africa. Journal of African Business. 12(1), 31-50. https:/doi.org/10.1080/1536710x.2011.555259

Kummer-Noormamode, S., 2014. Does trade with China have an impact on African countries' growth? African Development Review. 26(2), 397-415. https:/doi.org/10.1111/1467-8268.12100 
Large, D., 2008. Beyond "Dragon in the Bush": The study of China-Africa relations. African Affairs. 107, 45-61. https://doi.org/10.1093/afraf/adm069

Lenzen, M., Kanemoto, K., Moran, D. et al., 2012. Mapping the structure of the world economy. Environmental Science \& Technology. 46, 8374-8381.

Lenzen, M., Moran, D., Kanemoto, K. et al., 2013. Building Eora: a global multi-regional input-output database at high country and sector resolution. Economic Systems Research. 25, 20-49.

Leontief, W., Ford, D., 1970. Environmental repercussions and the economic structure: An input-output approach. The Review of Economics and Statistics. 52, 262-271. https:/doi.org/10.4324/9781315197715-18

Li, Y.L., Chen, B., Han, M.Y., Dunford, M., Liu, W., Li, Z., 2018. Tracking carbon transfers embodied in Chinese municipalities' domestic and foreign trade. Journal of Cleaner Production. 192, 950-960. https://doi.org/10.1016/j.jclepro.2018.04.230

Liu, B., Wang, D., Xu, Y., Liu, C., Luther, M., 2018. A multi-regional input-output analysis of energy embodied in international trade of construction goods and services. Journal of Cleaner Production. 201. 439-451. https:/doi.org/10.1016/j.jclepro.2018.08.029

Liu, X., Ishikawa, M., Wang, C., Dong, Y., Liu, W., 2010. Analyses of $\mathrm{CO}_{2}$ emissions embodied in Japan-China trade. Energy Policy. 38, 1510-1518. https:/doi.org/10.1016/j.enpol.2009.11.034

Long, R., Li, J., Chen, H., Zhang, L., Li, Q., 2018. Embodied carbon dioxide flow in international trade: A comparative analys is based on China and Japan. Journal of Environmental Management.

209 ,

371-381. https:/doi.org/10.1016/i.jenvman.2017.12.067

Long, X., Ji, X., 2019. Economic Growth Quality, Environmental Sustainability, and Social Welfare in China - Provincial Assessment Based on Genuine Progress $\begin{array}{lllll}\text { Indicator } \quad \text { (GPI). } & \text { Ecological } & \text { Economics. } & 159, & 176 .\end{array}$ https:/doi.org/10.1016/j.ecolecon.2019.01.002

López, L.A., Arce, G., Zafrilla, J.E., 2013. Parcelling virtual carbon in the pollution haven hypothesis. Energy Economics. 39, 177-186. https:/doi.org/10.1016/j.eneco.2013.05.006

Matsumoto, K., 2018. Climate change impacts on socioeconomic activities through labor productivity changes considering interactions between socioeconomic and climate systems. Journal of Cleaner Production. 
https://oi.org/10.1016/j.jclepro.2018.12.127

Meng, J., Mi, Z., Guan, D., Li, J., Tao, S., Li, Y., Feng, K., Liu, J., Liu, Z., Wang, X., Zhang, Q., Davis, S.J., 2018a. The rise of South-South trade and its effect on global $\begin{array}{llll}\mathrm{CO}_{2} & \text { emissions. } & \text { Nature } & \text { Communications. }\end{array}$ https $/ /$ doi.org/10.1038/s41467-018-04337-y

Meng, J., Zhang, Z.K., Mi, Z., Anadon, L.D., Zheng, H., Zhang, B., Shan, Y.L., Guan, D.B., 2018b. The role of intermediate trade in the change of carbon flows within China. Energy $\quad$ Economics. 303-312. https:/doi.org/10.1016/j.eneco.2018.10.009

Mi, Z., Meng, J., Guan, D., Shan, Y., Song, M., Wei, Y.M., Liu, Z., Hubacek, K., 2017. Chinese $\mathrm{CO}_{2}$ emission flows have reversed since the global financial crisis. Nature Communications. 8(1), 1712. https://doi.org/10.1038/s41467-017-01820-w

Montinari, L., Prodi, G., 2011. China's impact on intra-African trade. Chinese Economy. 44(4), 75-91. https:/doi.org/10.2753/ces1097-1475440404

Mullings, R., Mahabir, A., 2018. Growth by Destination: The role of trade in Africa's recent growth episode. World Development. 102, 243-261. https:/doi.org/10.1016/j.worlddev.2017.10.009

Nabernegg, S., Bednar-Friedl, B., Muñoz, P., Titz, M., Vogel, J., 2019. National policies for global emission reductions: Effectiveness of carbon emission reductions in international supply chains. Ecological Economics. 158, 146-157. https://doi.org/10.1016/j.ecolecon.2018.12.006

Obuah, E., 2012. Trade between China and Africa: Trends, changes, and challenges. International Journal of China Marketing. 2, 74-88. https:/doi.org/10.1111/j.1467-8268.2013.12031.x

Pan, J., Phillips, J., Chen, Y., 2008. China's balance of emissions embodied in trade: Approaches to measurement and allocating international responsibility. Oxford Review of Economic Policy. 24(2), 354-376. https:/doi.org/10.1093/oxrep/grn016

Paltsev, S.V., 2001. The Kyoto protocol: Regional and sectoral contributions to the carbon leakage. The Energy Journal. 22(4), 53-79. https:/doi.org/10.5547/issn0195-6574-ej-vo122-no4-3

Peh, K.S.-H., Eyal, J., 2010. Unveiling China's impact on African environment. Energy Policy. 38, 4729-4730. https://oi.org/10.1016/j.enpol.2010.02.028

Peters, G.P., Minx, J.C., Weber, C.L., Edenhofer, O., 2011. Growth in emission 
transfers via international trade from 1990 to 2008. Proceedings of the National Academy of Sciences. 108, 8903-8908. https://doi.org/10.1073/pnas. 1006388108

Peters, G.P., Hertwich, E.G., 2008. $\mathrm{CO}_{2}$ embodied in international trade with implications for global climate policy. Environmental Science \& Technology. 42, 1401-1407. https://doi.org/10.1021/es072023k

Richmond, A.K., Kaufmann, R.K., 2006. Is there a turning point in the relationship between income and energy use and/or carbon emissions? Ecological Economics. 56, 176-189. https://doi.org/10.1016/j.ecolecon.2005.01.011

Su, B., Ang, B.W., 2011. Multi-region input-output analysis of CO2 emissions embodied in trade: The feedback effects. Ecological Economics. 71(15), 42-53. https://doi.org/10.1016/j.ecolecon.2011.08.024

Su, B., Ang, B.W., 2012. Structural decomposition analysis applied to energy and emissions: Some recent developments. Energy Economics. 34(1), 177-188. https:/doi.org/10.1016/j.eneco.2011.10.009

Su, B., Thomson, E., 2016. China's carbon emissions embodied in (normal and processing) exports and their driving forces, 2006-2012. Energy Economics. 59, 414-422. https://doi.org/10.1016/j.eneco.2016.09.006

Shahbaz, M., Kumar Tiwari, A., Nasir, M., 2013. The effects of financial development, economic growth, coal consumption and trade openness on $\mathrm{CO}_{2}$ emissions in South Africa. Energy Policy. 61, 1452-1459. https://doi.org/10.1016/j.enpol.2013.07.006

Steen-Olsen, K., Owen, A., Hertwich, E.G., Lenzen, M., 2014. Effects of sector aggregation on $\mathrm{CO}_{2}$ multipliers in multiregional input-output analyses. Economic Systems Research, 26. 284-302. https//doi.org/10.1080/09535314.2014.934325

Tukker, A., Dietzenbacher, E., 2013. Global multire gional input-output frameworks: An introduction and outlook. Economic Systems Research. 25, 1-19. https $/ /$ doi.org/10.1080/09535314.2012.761179

Wiebe, K.S., Bruckner, M., Giljum, S., Lutz, C., 2012. Calculating energy-related $\mathrm{CO}_{2}$ emissions embodied in international trade using a global input-output model. Economic Systems $\quad$ Research. 24, 113-139. https:/doi.org/10.1080/09535314.2011.643293

Wiedmann, T., Lenzen, M., Turner, K., Barrett, J., 2007. Examining the global environmental impact of regional consumption activities - Part 2: Review of input-output models for the assessment of environmental impacts embodied in trade. Ecological Economics. 61, 15-26. https://doi.org/10.1016/j.ecolecon.2006.12.003 
Wiedmann, T., 2009. A review of recent multi-region input-output models used for consumption-based emission and resource accounting. Ecological Economics, Special Section: Analyzing the global human appropriation of net primary production - processes, trajectories, implications. 69, 211-222. https:/doi.org/10.1016/j.ecolecon.2009.08.026

World bank, 2018, https $/ /$ data.worldbank.org/

Wu, X.F., Chen, G.Q., 2018. Coal use embodied in globalized world economy: From source to sink through supply chain. Renewable and Sustainable Energy Reviews. 81, 978-993. https://doi.org/10.1016/j.rser.2017.08.018

Wu, X.D., Guo, J.L., Ji, X., Chen, G.Q., 2019. Energy use in world economy from household-consumption-based perspective. Energy Policy. 127, 287-298. https:/doi.org/10.1016/j.enpol.2018.12.005

Zhang, P., Deschenes, O., Meng, K., Zhang, J., 2018. Temperature effects on productivity and factor reallocation: Evidence from a half million Chinese manufacturing plants. Journal of Environmental Economics and Management. 88, 1-17. https://doi.org/10.1016/j.jeem.2017.11.001

Zhong, Z., Jiang, L., Zhou, P., 2018. Transnational transfer of carbon emissions embodied in trade: Characteristics and determinants from a spatial perspective. Energy. 147, 858-875. https://doi.org/10.1016/j.energy.2018.01.008

Zhu, Y., Shi, Y., Wu, J., Wu, L., Xiong, W., 2018. Exploring the characteristics of $\mathrm{CO}_{2}$ emissions embodied in international trade and the fair share of responsibility. Ecological Economics. 146, 574-587.https://doi.org/10.1016/j.ecolecon.2017.12.020 